\title{
Differences in labour market outcomes between natives, refugees and other migrants in the $\mathrm{UK}^{1}$
}

\begin{abstract}
Using 2010-2017 data we compare the labour market outcomes of refugees (those who migrated to seek asylum), natives (UK-born), and other migrants in the UK (work, study and family migrants). The results indicate that refugees are less likely to be employed and earn less than natives and other migrants. The evidence suggests that differences in health status (particularly mental health) may be one of the factors that partly explain these gaps. Employment growth of refugees between 2010 and 2016 was significantly higher than that of other migrants, but this was not the case for earnings.
\end{abstract}

Keywords: UK, refugees, labour markets, immigration JEL Classification: F22, J31

This version: 14 April 2018

\author{
Isabel Ruiz \\ Harris Manchester College \\ University of Oxford \\ Mansfield Rd \\ Oxford, OX1 3TD, UK \\ Email: isabel.ruiz@economics.ox.ac.uk
}

\author{
Carlos Vargas-Silva (contact author) \\ Centre on Migration, Policy and Society (COMPAS) \\ University of Oxford \\ 58 Banbury Rd \\ Oxford, OX2 6QS, UK \\ Email: carlos.vargas-silva@compas.ox.ac.uk
}

\footnotetext{
${ }^{1}$ Thanks to Esther Arroyo-Arenas, Francesco Fasani, Zovanga Kone and Jean-Francois Maystadt for helpful comments on previous versions of this paper. This paper is based on data from the secured access version of the UK Labour Force Survey produced by the ONS and supplied by the UK Data Service. The use of the data in this work does not imply the endorsement of ONS or the Secure Data Service at the UK Data Archive in relation to the interpretation or analysis of the data.
} 


\section{Introduction}

While the majority of the forcibly displaced stay within the borders of their countries of birth or migrate to neighbouring developing countries, there has been a substantial increase in asylum applications in developed countries. In the UK, for example, the number of asylum applications increased by 70\% from 2010 to 2016 (Home Office, 2017). Many of these asylum applicants will be granted protection, enabling them to remain in the country and enter the British labour market. The UK Government has also committed to accept 20,000 additional Syrian refugees for resettlement by 2020 (Home Office, 2015). These developments have spurred a growing interest in exploring the labour market outcomes of refugees and how these outcomes compare to those of other UK residents.

This paper explores differences in labour market outcomes between UK natives (i.e. UK-born), those who migrated to seek asylum (denoted as refugees in the following discussion) ${ }^{2}$ and those who migrated for other reasons (employment, family, study). While there is a rich literature on the economic outcomes of migrants in the UK (e.g. Clark and Lindley, 2009; Drinkwater et al., 2009; Dustmann and Fabbri, 2003), there is a scarcity of studies looking at the specific case of refugees. The main reason for this is that until recently there were no datasets available that indicated whether migrants had moved to the UK in order to seek asylum. This changed in 2010 when a question which enquires about the main reason for original migration to the country was added to the UK Labour Force Survey (LFS). We make use of this question and dataset in our paper.

The contribution of our paper is descriptive as there is no exogenous factor affecting selection into refugee status. However, in order to address possible concerns

\footnotetext{
2 In Section 3, we provide a detailed explanation of who is counted as a "refugee" in the dataset and how this might differ from other possible definitions.
} 
about bias related to self-identification as a refugee we use administrative Home Office data on the nationality of individuals granted protection in the UK to develop an alternative strategy to identify refugees in the dataset. We also assess the possible consequences of unobserved selection bias related to the category of asylum migrants by following the approach suggested by Oster (2017).

There are several reasons for which we could expect refugees to have worse outcomes than other migrants, particularly those who migrate for employment reasons. First, refugee skills may be less readily transferable across countries than those of other migrants and differences in the main motivation to migrate suggest that refugees may be less favourably selected for labour market success in the host country (Cafferty et al., 1983; Chiswick, 1999; Constant and Zimmermann, 2005). Second, asylum seekers in many countries face lengthy legal restrictions to access the labour market while their claim is being evaluated (Allsopp el at., 2014) and periods of labour market inactivity can have adverse long-term consequences (Chin, 2005; Fransen et al., 2017). Third, many refugees have experienced traumatic events that affect their mental and physical health and ability to work (Bhui, 2003; Giuntella et al., 2018; Turner et al., 2003; Warfa et al., 2006).

Other factors suggest that refugees could have better outcomes than other migrants over the long run. Refugees are often less likely to return home than other migrants as they face a higher risk of harm or persecution in their country of origin. The smaller likelihood of return results in a greater incentive to invest in host country human capital (Borjas, 1982: Cortes, 2004). As such, refugees could catch up and perhaps even outperform other migrants over time. It could also be the case that refugees from some countries are positively self-selected (Borjas, 1987). The typical example is entrepreneurs in communist countries who had experience confiscation of 
land and other assets in the home country. These entrepreneurs do not fit in the economic system in their home countries and may be better off in a market economy.

Our findings suggest that refugees have worse labour market outcomes than natives and other migrants. In particular, those who migrated to the UK with the intention of claiming asylum are less likely to be in employment, have weekly earnings which are lower, earn less per hour and work fewer hours than natives and those who migrated for work reasons. We also explore some of the possible reasons for the gap between refugees and other migrants and find that differences in health status (particularly mental health) and, to some degree, English proficiency could partly explain the gap between refugees and other groups. In terms of convergence, we found that there was higher growth in the employment rates of refugees from 2010 to 2016 relative to other migrants. As such, there is catching up over time in terms of employment. However, there is less evidence of catching up in terms of weekly earnings or hourly salary. This lack of evidence could be explained by the fact that those refugees who are likely to receive lower salaries find employment gradually and thus push down average wages in comparison to what we would observe if we could follow the same set of employed refugees over time.

\section{Conceptual background}

In this section we discuss in more detail why the labour market outcomes of refugees might differ from those of other migrants and natives. First, we use a simple twocountry model to explain the impact of conflict exposure/insecurity on the characteristics of the migrant group. The return to migration $(r)$ is a function of earnings in the foreign country $A\left(W_{A}\right)$ and home country $B\left(W_{B}\right)$, security levels in the foreign $\left(S_{A}\right)$ and home $\left(S_{B}\right)$ countries, and the cost of migration $(C)$. That is:

$$
r=\left(W_{A}-W_{B}\right)+\varphi\left(S_{A}-S_{B}\right)-C
$$


If $r>0$ the individual is better off abroad (i.e. in country A). Economic factors will determine the likelihood of migration when security conditions are similar across countries $\left(S_{A}=S_{B}\right)$. In this scenario those who are more likely to make an economic gain will migrate. On the other hand, if there is a positive security gap (i.e. $S_{A}>S_{B}$ ) it is possible for $r$ to be positive, even if the earnings gap is negative (i.e. $W_{A}<W_{B}$ ). In this scenario those affected by conflict and insecurity might migrate even if they expect to be worse off in economic terms in the host country. This idea is supported by a substantial literature suggesting that those who migrate to seek asylum are less favourably selected for initial labour market success in the host country in comparison to other migrants (Cafferty et al., 1983; Chiswick, 1999; Constant and Zimmermann, 2005).

The $C$ parameter also plays a key role. Many of those affected by insecurity are unlikely to be able to afford the cost of migration. As such, those from better off families might be more likely to leave the country in response to high levels of insecurity (Fransen et al., 2017; Van Hear, 2006). Moreover, the costs of migration could be lower for the more educated (Chiquiar and Hanson, 2005). For instance, those with higher levels of education may be better able to manage the complex asylum rules of countries such as the UK.

The security/economic incentives for migration only offer a partial account of the story for many refugees. Borjas (1987) highlighted the possibility of "refugee sorting". This refers to migrants who are selected from the lower tail of the home country income distribution but end up in the upper tail of the host country distribution. This could relate, for instance, to minority groups who are discriminated in the home country or migration from a non-market economy where the set of skills 
rewarded is different from the host economy (e.g. entrepreneurs in communist countries).

Also, in many cases the choice of final destination on the part of refugees is made after arriving at a safe first country of asylum (e.g. neighbouring country). At that point, economic incentives are likely to play a major role for the decision of onward migration for individuals who initially left their home countries for security reasons (Vargas-Silva, 2017). ${ }^{3}$

Post-migration factors can also result in key differences between refugees and other migrants (or natives) in countries such as the UK. First, while there have been some policy changes over time (see Section 3 for details), the majority of asylum seekers in the UK have not been able to legally access the labour market immediately after submitting their application for asylum (Gower, 2016). There is an extensive evidence base suggesting that periods of labour market inactivity can affect future labour market outcomes by leading to psychological discouragement and deterioration of skills (Chin, 2005; Fransen et al., 2017).

Second, asylum seekers are subject to a period of high uncertainty while their claim is being evaluated (i.e. "limbo period") and this could affect their future labour market outcomes. For instance, Hainmueller et al. (2016) show that in Switzerland one additional year of waiting for an asylum decision reduces the future employment rate of refugees by 4 to 5 percentage points.

Third, many refugees have experienced traumatic events (e.g. violence, persecution, rape, torture, shortages of food) that could affect their health. In fact,

\footnotetext{
${ }^{3}$ Note that direct resettlement accounts for a very small share of refugee inflows in the UK. As we explain later in the paper, our sample is limited to individuals who arrived in the UK on or before 2006. Data on resettlement is available since 2004. During 2004-2006 close to 927 refugees were resettled in the UK (including dependants) compared to the 99,785 applications for asylum (including dependants) made during the same period.
} 
there is substantial evidence in the health literature suggesting that refugees have poor health outcomes and are more likely to suffer from mental health conditions than other migrants (Bhui, 2003; Giuntella et al., 2018; Turner et al., 2003; Warfa et al., 2006). Mental health conditions have been shown to have a detrimental impact on labour market outcomes (Frijters et al., 2010; Webber et al., 2015).

On the other hand, previous evidence has highlighted that refugees often have a smaller likelihood of returning home compared to other migrants. Cortes (2004) uses a two period model and shows that a lower likelihood of return leads to a greater incentive to invest in host country specific human capital. She also presents evidence that refugees who arrived in the United States from 1975 to 1980 made greater earnings gains over time than other migrants in the same arrival cohort. Borjas (1982; 2014) also highlights that migrants who face higher migration costs should assimilate faster. For instance, Borjas (1982) shows that Cubans in the United States, the majority of whom are political refugees and unlikely to return home, had a higher rate of economic progress than other Hispanic migrants. This economic progress was the result of greater investments in U.S. human capital. As such, refugees in our sample could make greater advances over time in comparison to other migrants.

\section{The UK asylum system and the definition of "refugee"}

We use information on the motivation for original migration in order to identify "refugees". The information on motivation for migration is not available in the regular LFS dataset. As such, we make use of the secured access version of the LFS which contains this information. We define refugees as foreign born individuals who selected "seeking asylum" as their main reason for migration to the UK. As shown in Table 1, the main reasons for migration of the UK foreign-born population are family (e.g. joining a British/non-British spouse, as a dependent minor) and employment. 
Only $6 \%$ of those in our sample selected seeking asylum as the main reason for original migration. This coincides with other datasets which suggests that seeking asylum is not a major driver of migration to the UK (Blinder, 2016).

[Table 1]

Our definition of a refugee differs from other potential definitions, such as the legal one. For instance, a person who requests asylum in the UK and is waiting for a decision on that claim is known as an asylum seeker. As shown in Figure 1, the number of annual asylum applications in the UK has fluctuated between close to 1,500 in 1979 to a peak of 103,000 in 2002 . Over the last decade the UK has received an average of 31,000 asylum applications per year (including dependants).

[Figure 1]

The UK Government aims to decide asylum claims within six months of application. ${ }^{4}$ Asylum seekers are eligible for government cash assistance and free housing while they wait for a decision. As of 2016, this cash assistance entailed a weekly payment of $£ 36.95$ per person in the household. Asylum seekers who received housing assistance cannot select the location of residence and are distributed across the country based on housing availability under the UK asylum dispersal programme (Bakker, 2016). ${ }^{5}$

In our analysis, we look at individuals who entered the UK on or before 2006. Until July 2002, asylum seekers could apply for permission to work if they had been

\footnotetext{
4 This is for an initial decision. In case of a negative decision, the asylum seeker can make an appeal. Dustmann et al. (2017) using data for 2000-2014 estimate that the UK is the EU country with the highest average rate of asylum applications cleared over the period.

5 Please note that this housing allocation is just for the period of the asylum application. There is no location restriction for those who are granted refugee status. For further discussion on the potential implications of government (or EU wide) allocation of refugees see Fernández-Huertas Moraga and Rapoport (2015) and Delacretaz et al. (2016).
} 
waiting for six months for an initial decision. ${ }^{6}$ From July 2002 to February 2005 this concession was eliminated and granting the permission to work was at the discretion of case workers. According to the UK Government, the change in the standard six month concession responded to this practice becoming irrelevant given that "the vast majority—around 80 per cent—of asylum seekers receive a decision within six months" (House of Lords, 2012). From February 2005, asylum seekers could apply for permission to work if they had been waiting for twelve months for an initial decision on their claim. This rule change was made to comply with an EU directive (Gower, 2016). The delay in reaching a decision must not have been the fault of the asylum seeker (e.g. missing an appointment or document). Note that an asylum seeker who has already been granted permission to work will continue to have this permission even if the policy changes for future applicants. ${ }^{7}$

Refused asylum seekers are expected to make arrangements for leaving the UK. There are voluntary programs of return, but the Government can also deport the individual. ${ }^{8}$ Someone who receives a positive decision on his or her asylum claim has refugee status. ${ }^{9}$ As also shown in Figure 1, the annual number of grants of protection has fluctuated between 740 in 1979 to 41,000 in 2001. The UK has given an average of 8,620 grants of protection per year since 2007. According to the United Nations High Commission for Refugees (2016), the UK had the fourth largest stock of

\footnotetext{
${ }^{6}$ Please note that some employers could perceive that hiring an asylum seeker with the legal right to work is risky given that if the applicant does not obtain official status, he/she would have to leave the job.

${ }^{7}$ Recently this policy has become more restrictive. Since late 2010, asylum seekers can only take jobs included in the UK's shortage occupation list. This change should not affect the refugees in our sample.

${ }^{8}$ See Collyer and Kulasinghe (2010) and Gibney (2008) for further discussion on UK deportation policies.

${ }^{9}$ In practice, some of those who apply for asylum are given humanitarian protection status instead of refugee status. In this case the person has a need for protection but does not meet the criteria for refugee status. The overall implications are similar for the purpose of the discussion in this paper.
} 
individuals with refugee status (i.e. 123,067) among European Union members in 2015 (behind Germany, Sweden and France).

After receiving refugee status the person has unrestricted access to the UK labour market. At that point the person can also register for a national insurance number in order to access welfare benefits. Most of those who received protection in the UK can apply for permanent settlement after a few years and at a later stage for British nationality. These individuals with permanent settlement or British nationality are no longer under "refugee status", but are still considered refugees in our definition because they came to the UK for asylum purposes. In fact, as we will show in the next section, the majority of refugees in our sample are already British nationals.

The main countries of origin of refugees as identified by us in the LFS are Somalia, Afghanistan, Sri Lanka, Iraq and Zimbabwe (Table 2). This contrasts with the main countries of origin of other migrants as identified in the LFS: India, Poland, Pakistan, Germany and Ireland.

[Table 2]

As we explained in detail below, one of the concerns of using self-reported reason for migration is that some individuals who migrated to seek asylum might not report this in the survey. One possible way to explore this concern is to look at other sources of information on the origin of refugees in the UK. In column 3 of Table 2 we report administrative data from the UK Home Office on the main nationalities of those who were granted protection in the UK during the 2001-2006 period (main applicants). While the information is not available for the pre-2001 period, this information can provide a benchmark to compare the information from the LFS. Four of the top five countries in column 5 are also top five countries in column 1 . The exceptions are Sri Lanka and Iran. Sri Lanka does not appear in column 5, but 
actually occupies the 8th position in the Home Office data. Iran does not appear in column 1, but actually occupies the 6th position in the LFS data. As such, the Home Office and LFS data broadly coincide on the main countries of origin of refugees.

\section{Data and methodology}

Data for this paper comes from the secured access version of the UK LFS. The information on main reason for migration is only available from 2010 onwards. We use all the data available at the moment of writing the paper, that is, from Q1 2010 to Q3 2017. The LFS interviews individuals for five consecutive quarters. We only keep respondents in the first wave of the LFS in order to avoid repeating the same individuals. As such, our data set is made up of 31 cross-sections. We also limit the sample to individuals who are between 21 and 58 years of age in 2010, i.e. at most 65 years of age in 2017. Finally, the foreign-born component of the sample is limited to individuals who migrated to the UK on or before $2006 .{ }^{10}$ This means that all migrants in the sample entered the UK before the financial crisis and have spent more than three years living in the country by 2010 . Overall, we have complete information for 279,634 UK natives, 2,360 refugees and 35,844 other migrants.

Our baseline estimations are a series of regressions along the following lines:

$$
\begin{aligned}
y_{i}=\alpha_{0}+\alpha_{1} W_{i}+\alpha_{2} S_{i}+\alpha_{3} F_{i}+\alpha_{4} R_{i}+\alpha_{5} O_{i}+ \\
\quad \alpha_{6} T U K_{i}+\gamma_{p}+\tau_{t}+\sigma_{q}+\theta X_{i}+\varepsilon_{i}
\end{aligned}
$$

Where $y_{i}$ is the outcome of interest, $W_{i}$ is a dummy for migration for work reasons, $S_{i}$ is a dummy indicating migration for study reasons, $R_{i}$ is a dummy indicating migration for asylum reasons, $F_{i}$ is a dummy indicating migration for family reasons, $O_{i}$ is a dummy indicating other reasons for original migration (including visitors),

\footnotetext{
10 The UK Office for National Statistics has suggested that the LFS response rate is lower for recent migrants (i.e. those who arrived within the previous year). This should not be a major problem in our analysis as we limit the analysis to those who have been in the country for more than three years.
} 
$T U K_{i}$ controls for years since migration (equal to zero for natives), $\gamma_{p}$ are fixed effects for local authority, $\tau_{t}$ are year dummies, $\sigma_{q}$ are quarter dummies, $X_{i}$ are the individual controls and $\varepsilon_{i}$ is the error term. We estimate the model for all individuals and separately by gender.

Those who migrated for employment reasons are likely to have the highest success in the labour market as they are more likely to be selected on factors that relate to economic performance in the host country. On the other hand, previous studies suggest that family migrants tend to have worse labour market outcomes than economic migrants (e.g. Aydemir, 2011; Bevelander and Pendakur, 2014).

We concentrate the analysis on four labour market outcomes. First, we look at differences in the likelihood of being in employment (dummy variable). ${ }^{11}$ Second we look at the differences in weekly earnings. Next we explore if differences in weekly earnings are the result of a gap in salary and/or hours worked. For this purpose we look at differences between natives, refugees and other migrants in hourly salary and weekly hours worked.

Table 3 provides descriptive statistics for these four dependent variables. Those who migrated to seek asylum are, on average, 22 percentage points less likely than natives to be in employment and have the lowest employment rates among the migrant groups. The unconditional difference in weekly earnings between those who migrated to seek asylum and UK natives is $£ 196$. Once again, those who migrated to claim asylum have the lowest weekly earnings among all migrant groups. Consistent with these two gaps, those who migrated to seek asylum report a lower hourly wage and weekly hours worked than UK natives and other migrants.

\footnotetext{
${ }^{11}$ We also tried a Probit model instead of the linear probability model when using the employment dummy as the dependent variable and results are consistent across models.
} 
There is a gender gap in labour market outcomes with men outperforming women in most categories. Furthermore, comparing across groups and genders is clear that, for the most part, women who migrated to seek asylum are at a substantial disadvantage relative to men who migrated for the same reason and other women.

[Table 3]

Weekly earnings, hourly salary and weekly hours worked are included in logs in the regressions. We control for gender, age (a quartic), marital status, education, religion, health status and UK nationality. Table 4 provides descriptive statistics for the control variables. Those who migrated to seek asylum are more likely to be Muslim, come from Africa and report a health problem. In addition, around $62 \%$ of refugees in our sample are UK nationals. The Appendix provides details on the definition of all the variables used in the estimation.

[Table 4]

In a second step we limit the sample to foreign-born individuals and estimate:

$$
\begin{aligned}
y_{i}=\alpha_{0}+\alpha_{1} S_{i}+\alpha_{2} F_{i}+\alpha_{3} R_{i}+\alpha_{4} O_{i} & +\sum_{j=1}^{7} \rho_{j} T G U K_{j i} \\
& +\gamma_{p}+\tau_{t}+\sigma_{q}+c_{i}+\theta X_{i}+\varepsilon_{i}
\end{aligned}
$$

In this case $T G U K$ refers to dummies indicating time since migration grouped in three-year periods (e.g. $T G U K_{l i}$ is one for those who arrived in the country from 4 to 6 years ago, while $T G U K_{7 i}$ indicates those with $22-24$ years in the country). In this case, we include country of origin dummies $\left(c_{i}\right)$, but also show results using region of origin instead (i.e. Africa, Americas, Asia, Europe, Other).

We also look at convergence in outcomes over time. Two exercises are conducted for this purpose. First, we limit the sample to natives and each of the migrant groups (e.g. natives and those who came for work reasons) and estimate:

$$
y_{i}=\alpha_{0}+\sum_{j=1}^{8} \rho_{j} T G U K_{j i}+\gamma_{p}+\tau_{t}+\sigma_{q}+\theta X_{i}+\varepsilon_{i}
$$


Then we plot $\rho_{1}, \rho_{2}$, etc. This separation also allows use to explore the long-term differences between refugees and other migrants. As explained by Bauer et al. (2013), most studies looking at the labour market outcomes of forced migrants are focused on outcomes one to four years after arrival and less is known about long-term dynamics.

For the second exercise we limit the dataset to the first and last years with full data (i.e. Q1 to Q4 of 2010 and Q1 to Q4 2016). As shown in Table 5, the employment rate of the refugee group increased by 20 percentage points between 2010 and 2016, compared to only 1 percentage point increase for other migrants. On the other hand, there was a decrease in average weekly earnings for the refugee group, while average weekly earnings increased for other migrants. The increase in weekly earnings for non-refugees was driven by an increase in hourly salary.

[Table 5]

In order to explore this further we limited the sample to migrants only and estimated several regressions along the following lines:

$$
\begin{array}{r}
y_{i, t}=\alpha_{0}+\alpha_{1} D 2016_{t}+\alpha_{2} R_{i}+\alpha_{3} D 2016_{t} * R_{i}+\sum_{j=1}^{7} \delta_{j} T G U K_{j i} \\
+\gamma_{p}+\sigma_{q}+c_{i}+\theta X_{i, t}+\varepsilon_{i, t}
\end{array}
$$

Where $D 2016_{t}$ is a dummy for the year 2016. In this estimation $\alpha_{1}$ provides information on the growth in the labour market outcome (e.g. weekly earnings) of non-refugees from 2010 to 2016 . The sum of $\alpha_{1}$ and $\alpha_{3}$ provides the growth in the labour market outcome for refugees between 2010 and 2016. Meanwhile, $\alpha_{3}$ is the growth in the labour market outcome of refugees relative to other migrants between 2010 and 2016.

Finally, we explore several possible channels that could explain differences between refugees and other migrants and check the robustness of our results by using an alternative way of identifying refugees in the LFS. The main channel explored is 
differences in health, but the analysis also explores the limited evidence available on differences in English proficiency. For the robustness check we use Home Office administrative data.

\section{Main results}

\subsection{Differences in outcomes between UK natives and migrants}

Table 6 provides the baseline results regarding differences in employment and weekly earning outcomes between refugees, natives and other migrants. Looking at column 5 which includes all controls and fixed effects, estimates suggest that those who migrated to claim asylum are 19 percentage points less likely to be in employment than UK natives. In contrast, there is no statistical difference in the likelihood of employment between those who migrated for work reasons and UK natives. Also, there is a 5 percentage point gap in the likelihood of employment between those who migrated for study reasons and natives, while this gap is 15 percentage points for those who migrated for family reasons.

In the estimation in column 5 , time in the $\mathrm{UK}$ is set equal to zero for natives. We recognise that this may be an imperfect approach as permanence in the host country is also a measure of experience and knowledge of the local labour market which should be high for natives. As shown in column 4, excluding this variable does not alter the main conclusions of the analysis but the coefficient is smaller. In this case, the results suggest that those who migrated for asylum reasons are 14 percentage points less likely to be in employment than natives. ${ }^{12}$

These results are not entirely surprising. All previous studies looking at refugees in the UK suggest that they fare worse than other migrants in terms of labour

\footnotetext{
12 We tried two other specifications: (1) using share of life time in the UK (vs one for natives) and (2) equalling Time in the UK to age for natives. These adjustments did not change the results significantly and do not affect the main story of the paper.
} 
market outcomes (Campbell 2014; Lindely, 2000; Kausar and Drinkwater, 2010; Ruiz and Vargas-Silva, 2017). For instance, Ruiz and Vargas-Silva (2017) found that during 2005 - 2007 recent refugees in the UK were 10 percentage points less likely than other migrants to be in employment.

This is also consistent with studies looking at European level data and other European countries. For example, Dustmann et al. (2017), using data from the 2008 European Labour Force Survey, estimate that refugees in the EU are close to 11 percentage points less likely to be employed than economic (non-EU15) migrants. Bratsberg et al. (2016), using longitudinal data from Norway for 1990-2013, find that the male native-refugee employment gap is at its lowest point five years after arrival in the country, but it is still close to 20 percentage points at that time. For Denmark, Schultz-Nielsen (2017) suggests that the native-refugee men employment gap is 31 percentage points after 10 years in the country. There are similar studies suggesting a refugee gap in Finland (Sarvimäki, 2017). ${ }^{13}$

Looking at weekly earnings, and focusing on column 10 of Table 6, it is clear that all migrant groups earn less than UK natives. The coefficient is larger for those who came to claim asylum ( $76 \%$ gap). Among the other migrant groups, the gap is lower for those who migrated for work reasons (21\%) and higher for those who migrated for family reasons (44\%). If we look at the results in column 9, which does not include Time in the UK, the results suggest that there is a $58 \%$ weekly earnings gap between refugees and natives.

[Table 6]

Table 7 presents the results for hourly salary and hours worked. Migrants in all categories have a lower hourly salary than UK natives but, once again, the

\footnotetext{
${ }^{13}$ For further discussion of refugee integration in Nordic countries see the Nordic Economic Policy Review (2017).
} 
coefficient is of higher magnitude for those who migrated to claim asylum (i.e. 59\% lower hourly salary than UK natives), followed by family migrants (39\%). The refugee group also works fewer hours than UK natives (17\% gap). If we look at the results in columns 4 and 8 of Table 7, which do not include time in the UK in the estimation, the coefficients are smaller (44\% salary and 14\% hours gap for refugees), but overall still substantial. The combined effect of the lower hours worked and lower hourly salary explains the large gap in weekly earning between those who migrated to claim asylum and UK natives, but the major difference seems to be the hourly salary. [Table 7]

Table 8 indicates how these gaps across migrant groups differ by gender. The employment gap between refugee women and native women ( 25 percentage points) is substantially greater than the gap between refugee men and native men (13 percentage points). However, for the other variables (i.e. weekly earnings, hourly salary and hours worked) the relative gender specific gap is smaller for refugee women than for refugee men.

[Table 8]

\subsection{Differences in outcomes between migrant groups}

In Table 9, we focus on comparisons across migrant groups. In this case the reference category is those who migrated for work reasons. As expected given the results of the previous section, other migrant groups tend to do worse than "economic migrants" in the labour market. However, those who migrated to seek asylum are comparatively worse off among all groups. They are 13 percentage points less likely to be in employment, earn $43 \%$ less per week, have an hourly salary which is $27 \%$ lower and work $16 \%$ fewer hours than those who migrated for work reasons. Please note that the 
coefficients are typically a bit smaller when we include the controls for country of origin (i.e. versus controls for region of origin), but the difference is not large.

[Table 9]

\subsection{Convergence over time}

Table 10 presents the results from estimating equation (4) for each of the migrant groups. In this case the employment dummy is the dependent variable and each group is only compared to natives. The table suggests that there is convergence to the natives across most groups. In order to make this comparison clearer, Figure 2 plots the coefficients for all the labour market outcomes. In these plots the zero line represents the natives' outcomes.

[Table 10]

As explained above, there is evidence that even if refugees are sometimes at a substantial initial disadvantage, the gap might close over time due to factors such as larger investments in host country human capital (Borjas, 1982; Cortes, 2004). The plots in Figure 2 suggest that the employment and hours worked gap closes over time for refugees. There is some convergence in terms of hourly salary and weekly earnings, but the gap remains substantial for all periods. The story is somewhat different for the other groups, as other migrants' weekly earnings and hourly salary converge to the ones of natives over time.

[Figure 2]

It is important to keep in mind that the plots in Figure 2 do not take a series of factors into account. First, there could be selective out migration from the UK. If nonrefugees with worse outcomes leave the UK after a while, the gap between refugees 
and non-refugees will be overstated. ${ }^{14}$ Likewise, the estimates presented in this section are based on cross-sectional data for a seven year period. As such, we are not able to adjust for compositional changes across cohorts (see Borjas, 1985, 1999 for further discussion about the implications of this limitation). Ideally, we would be able to see the same cohort of migrants over time.

One possible way to somewhat address the differences in cohort is to compare the same cohort at two different points in time. In this case, we limit the analysis to 2010 and 2016 and estimate equation (5). Again, the sample only includes those migrants who arrived in the UK on or before 2006. As suggested by Table 11, refugees who arrived on or before 2006 have gained more in terms of the likelihood of employment than other migrants who also arrived during that period. The estimation suggest that the likelihood of employment of refugees increased by 16 percentage points relative to other migrants between 2010 and 2016. However, this increase in the likelihood of employment has not been accompanied by a similar relative increase in weekly earnings, hourly pay or hours worked.

\section{[Table 11]}

A possible explanation for the difference in results with other studies, such as Cortes (2004) for the United States or Ruiz and Vargas-Silva (2017) for the UK in the mid-2000s, is that we are not exploring results for a recent cohort of migrants, but for a cross-section of migrants that includes individuals who have been in the country for many years and any convergence might have occurred already for many. On other hand, some studies have similar findings to ours. For instance, Aydemir (2011) found that in Canada refugees start out with the lowest labour market participation rates

\footnotetext{
${ }^{14}$ Lubotsky (2007) presents a discussion of the implications of selective out-migration for the exploration on migrant integration.
} 
among migrants but have the fastest growth in participation. Yet, he finds that there is no convergence in weekly earnings for refugees.

It is also important to note that interpreting the results for outcomes other than employment is somewhat difficult, because the composition of the employed sample in each migrant group is likely to change over time in the host country. For instance, we can expect that migrants who are likely to receive lower salaries find employment gradually and thus push down average wages in comparison to what we would observe if we could follow the same set of constantly employed migrants over time.

\section{Channels}

\subsection{Health}

As mentioned above, there is ample evidence that those who migrate to seek asylum tend to have worse health than other migrants. This includes physical as well as mental health. Some argue that inadequate treatment of health conditions while waiting for an asylum decision often results in even worse health outcomes for refugees (Bakker et al., 2016). Studies for other countries also suggest that refugees experience a substantial increase in their participation in disability programs over time (Bratsberg et al., 2014).

In the estimations we controlled for self-reported health status. The coefficient for the baseline estimation with controls and fixed effects suggests that having a health condition/illness which has lasted twelve months or more leads to a 19 percentage points reduction in the likelihood of employment (see Table A2 in the Appendix). In our dataset, $37 \%$ of the refugees reported having this kind of health condition compared to $28 \%$ for other migrants and $34 \%$ for natives. This health status indicator can nonetheless mask important variations across individuals in terms of the impact of the condition on the type and amount of paid work that the respondent can 
undertake. As shown in columns 1 to 3 of Table 12, 69\% of refugees with health problems reported that the problem limits the kind or amount of work they can engage in compared to half of the natives and other migrants with health problems.

[Table 12]

In column 4 of Table 12, we show the results from a regression in which the dependent variable is a health related indicator and which controls for the variables presented in Table 4. The table shows coefficients for a dummy variable indicating that the individual migrated in order to claim asylum. The results suggest that refugees are 14 percentage points more likely than non-refugees to report a health problem which limits the type of work they can do and 17 percentage points more likely to report a health problem which limits the amount of work they can engage in. The types of health problems experienced by refugees and others are mostly similar, but there are some differences. The main difference is that refugees are more likely to report a mental health problem than non-refugees. This corresponds well with the evidence that suggest that refugees are particularly likely to experience mental health problems (Bhui, 2003; Giuntella et al., 2018; Turner et al., 2003; Warfa et al., 2006). This in turn has implications for labour market success (Banerjee et al, 2017; Chatterji et al., 2011). On the other hand, refugees are less likely to report suffering from respiratory problems. ${ }^{15}$

\subsection{English proficiency}

Several studies suggest that English proficiency is one of the main factors affecting the earnings of migrants in the UK (Dustmann and Fabbri, 2003). Studies for other countries have also pointed at local language proficiency as a key factor differentiating refugees and other migrants (Auer, 2018; Aydemir, 2011; Cortes,

\footnotetext{
${ }^{15}$ See Giuntella et al. (2018) for a full discussion of the link between reason for immigration and health outcomes in the UK.
} 
2004). Moreover, Lochmann et al. (2017) evaluate the impact of language training in France and found that the training had a higher effect on labor force participation for refugees compared to other groups such as family migrants. In the UK, there is anecdotic evidence that lack of English proficiency is an obstacle for refugees to obtain a national insurance number in order to prove that they have the right to work in the country (All Party Parliamentary Group on Refugees, 2017).

In the LFS, the information on English proficiency is only collected once every three years. For this reason, we only have limited information in this regard (i.e. quarter 3 of 2012 and quarter 3 2015). Still even with the limited sample, it is possible to observe some differences between refugees and other migrants. The data suggests that refugees are more likely to speak a language other than English at home (68\%) than other migrants (47\%). It is important to highlight nonetheless that the implications of this gap remain uncertain as language at home relates to patterns of intra-marriage, among many other factors. More telling is the fact that $16 \%$ of refugees reported that language problems have resulted in difficulties keeping or finding a job compared to $10 \%$ of other migrants.

In a second exercise, we look at information on English proficiency by country of birth from the 2011 English Census. ${ }^{16}$ The information is only available for handful of countries, but there is information available for Somalia, the main country of origin of refugees in our dataset. There were 99,250 Somalis counted in the 2011 English Census of whom only 27\% $(26,748)$ reported using English as their main language. This compares to $71 \%$ for those born in the rest of Africa and $45 \%$ for those born in India, the main country of origin of non-refugees in our sample.

\footnotetext{
${ }^{16}$ Please note that this dataset does not include Wales, Scotland and Northern Ireland.
} 
Finally, we have re-estimated the main regressions limiting the sample to those migrants who come from countries which use English as a language of instruction in higher education. This decreases the overall sample of migrants by about half. Given the substantial decrease in the sample size we consider these estimates as tentative. The results are presented in Table 13. It is still the case that those who migrated for asylum reasons are worse off than other immigrants, but the coefficients are smaller than those in Tables 6 and 7. Obviously, English as a language of instruction in higher education relates to many other factors and we are not claiming that these results provide unequivocal evidence that language plays a role in explaining the labour market gap for refugees, but the results point in that direction.

[Table 13]

\section{Robustness}

\subsection{Identification of refugees}

The main concern regarding the robustness of the results is the issue of selfidentification as someone who migrated to seek asylum. For instance, it is possible that the most (or perhaps least) successful refugees do not self-identify as such in the LFS. This would lead to bias in the results. There is no perfect solution to this problem. However, in this section we present results with alternative approaches to the identification of those who migrated to seek asylum in order to highlight the robustness of the results. In these exercises we assign a probability to each individual of being a refugee given his or her country of origin. We use Home Office administrative data to assign this probability. Previous studies for the UK have used similar approaches in order to identify refugees in the LFS before there was any 
information available on the main motivation for migration (e.g. Lindley, 2000; Kausar and Drinkwater, 2010).

Using Home Office data as previously noted, in this first exercise, for any individual from country $(j)$ we construct $S_{j}$ as the share of new refugees (i.e. main applicants granted asylum) in the $2001-2007$ period who come from this country. ${ }^{17}$ Then we use this share as a proxy for refugee status in the estimation. That is:

$$
S_{j}=\frac{\text { New Refugees }_{\mathrm{j}}}{\sum_{j=1}^{N} \text { New Refugees }_{\mathrm{j}}}
$$

The results of the robustness exercises are presented in the Appendix. As shown in column 1 of Table A3, those who come from countries that account for a larger share of the new refugees have worse labour market outcomes than other migrants. For instance, the estimates suggest that a 1 percentage point increase in the share of the refugee population accounted by those coming from a given country is associated with a 1.2 percentage point decrease in the probability of employment for those originating in that country.

Next we use the share of new refugees from a given country divided by the total population resident in the UK from that country in the first quarter of 2010. That is:

$$
S_{j}=\frac{\text { New refugees }_{\mathrm{j}}}{\text { Residents }_{\mathrm{j}}}
$$

This variable might be better at capturing the likelihood of being a refugee given the country of origin as some key source countries of refugees are also key source countries of other migrants. For example, Pakistan occupies the third place in countries of origin among the non-refugees and the eleventh place among refugees.

\footnotetext{
17 Information is not available for the pre-2001 period.
} 
Sri Lanka occupies the third place among the refugees and the fifteenth place among the non-refugees. Zimbabwe occupies the fifth place among the refugees and the fourteenth place among the non-refugees. The results using this alternative approach to identify refugees are presented in column 2 of Table A3. Again, the results confirm that those who are more likely to be refugees given their country of origin have worse labour market than other migrants.

\subsection{Selection on unobservables}

As a final check, we follow the suggestions of Oster (2017) bounding approach and explore the potential consequences of unobserved selection on the stability of the coefficient on the refugee dummy. ${ }^{18}$ The estimation requires the selection of $R_{\max }=$ $\Pi \widetilde{R}$, which essentially reflects the maximum explanatory power of a hypothetical regression that controls for all relevant observed and unobserved factors. In this case, $\widetilde{R}$ is the $R^{2}$ from the regression controlling for all observable factors. She suggests using $\Pi=1.3$. It is also necessary to specify $\delta$, the coefficient of proportionality between selection on observables and selection on unobservables. She suggests using $\delta=1$ (the case in which observables are at least as important as unobservables). Therefore, the analysis suggested by Oster (2017) evaluates the possible degree of omitted variable bias under the assumption that the selection on the observed controls is proportional to the selection on the unobserved controls. Table A4 provides information on the bounds for the coefficients under these assumptions. There are some minor differences in the coefficients, particularly for weekly earnings and hourly salary but the changes are not major and do not change the main patterns in the results presented above. It is also possible to estimate how much more important

\footnotetext{
${ }^{18}$ The analysis of Oster (2017) follows from the suggestions of Altonji et al. (2005) and the main point is that in addition to taking into account changes in the coefficients it is important to take account of changes in the $R^{2}$.
} 
selection on omitted variables would have to be than selection on observable controls for the true effect to equal zero. In general, we want this value of $\delta$ to be equal or greater than one and this is the case for all our estimations. For instance, selection on omitted variables would have to be 12.7 times larger than selection on observables for the employment regression. Overall, these analyses suggest robustness in our results.

\section{Conclusion}

The growth in the UK's refugee population raises important questions regarding longterm migrant labour market integration. Using secured access data which identifies the main reason for original migration to the UK, we explore differences in labour market outcomes of those who migrated to seek asylum, those who migrated for other reasons and natives.

Our results suggest that those who migrated to seek asylum have worse labour market outcomes than natives and other migrants, including a lower likelihood of employment, lower weekly earnings, lower hourly salary and lower number of hours worked. There is evidence of convergence over time between refugees and other migrants for the likelihood of being in employment. The gap closes more slowly for the other labour market outcomes.

There is also evidence for some possible explanations of the gap between refugees and other migrants including differences in health conditions and, to a limited degree, language proficiency. There are other possible channels that we cannot explore in our analysis but could be highly relevant. For instance, previous analysis suggests that a major barrier to securing employment for refugees relative to

other migrants is the lack of recognition of qualifications and previous work experience (Ager and Strang, 2008). Other studies have focused on the effect of 
waiting times for the asylum decision on posterior labour market outcomes (Hainmueller et al., 2016).

Overall, our analysis suggests that some of the initial economic disadvantages faced by refugees in the UK persist over time. Refugees have different characteristics from other migrants and policies that work for migrants in general may have to be adjusted to the particular situation and characteristics of refugees. Studies for other countries suggest that individualized integration plans can have a large positive impact on the labour market outcomes of disadvantaged migrants, including refugees (Sarvimäki and Hämäläinen, 2016). Among other policies, it seems that refugees can benefit from programmes that place particular attention on mental health issues and English proficiency to facilitate integration into the labour market.

Finally, it is important to note that our study only focuses on refugees who entered the UK on or before 2006. The analysis does not imply that the dynamics of newer refugees (e.g. recent Syrian refugees) will be similar to the ones in our sample. However, the same approach used in this paper could be applied to these new refugees during the upcoming years in order to enable this comparison. 


\section{References}

Ager, A. and A. Strang (2008) "Understanding Integration: A Conceptual Framework." Journal of Refugee Studies, 21(2): 166-191.

All Party Parliamentary Group on Refugees (2017) "Refugees Welcome? The Experience of New Refugees in the UK" Report by the All Party Parliamentary Group on Refugees, April, 2017.

Allsopp, J., Sigona, N. and J. Phillimore (2014) "Poverty Among Refugees and Asylum Seekers in the UK: An Evidence and Policy Review." IRiS Working Paper Series, No. 1/2014.

Altonji, J.G., Elder, T.E. and Taber, C.R. (2005) "Selection on Observed and Unobserved Variables: Assessing the Effectiveness of Catholic Schools," Journal of Political Economy, 113 (1): 151-184.

Auer, D. (2018) "Language Roulette - The Effect of Random Placement on Refugees' Labour Market Integration." Journal of Ethnic and Migration Studies, 44(3).

Aydemir, A. (2011) "Immigrant Selection and Short-Term Labor Market Outcomes by Visa Category." Journal of Population Economics, 24(2): 451-475.

Bakker, L., Cheung, S.Y. and Phillimore, J. (2016) "The Asylum-Integration Paradox: Comparing Asylum Support Systems and Refugee Integration in The Netherlands and the UK." International Migration, 54(4): 118-132.

Bauer, T.K., Braun, S. and Kvasnicka, M. (2013) "The Economic Integration of Forced Migrants: Evidence for Post-War Germany." The Economic Journal, 123(571): 998-1024.

Banerjee, S., Chatterji, P., and Lahiri, K. (2017) "Effects of Psychiatric Disorders on Labor Market Outcomes: A Latent Variable Approach Using Multiple Clinical Indicators." Health Economics, 26: 184-205.

Bevelander, P. and Pendakur, R. (2014) "The Labour Market Integration of Refugee and Family Reunion Immigrants: A Comparison of Outcomes in Canada and Sweden." Journal of Ethnic and Migration Studies, 40(5): 689-709.

Blinder, S. (2016) "Migration to the UK: Asylum." Migration Observatory Briefing.

Bhui K., Abdi A, Abdi M, Pereira S, Dualeh M, Robertson D, Sathyamoorthy G, Ismail H. (2003) "Traumatic Events, Migration Characteristics and Psychiatric Symptoms among Somali Refugees--Preliminary Communication." Social Psychiatry and Psychiatric Epidemiology, 38(1): 35-43.

Borjas, G.J. (1982) "The Earnings of Male Hispanic Immigrants in the United States." Industrial and Labor Relations Review, 35(3): 343-353.

Borjas, G.J. (1987) "Self-Selection and the Earnings of Immigrants." The American Economic Review, 77(4): 531-553.

Borjas, G.J. (2014) Immigration Economics. Harvard University Press.

Bratsberg, B., Raaum, O. and Røed, K. (2014) "Immigrants, Labour Market Performance and Social Insurance." Economic Journal, 124: F644-F683.

Bratsberg, B., Raaum, O. and Røed, K. (2016) "Labour Market Integration of Refugees in Norway" in F. Fasani editor, Refugees and Economic Migrants: Facts, Policies and Challenges, London: CEPR Press.

Cafferty P.S.J., Chiswick B.R., Greeley A.M., Sullivan, T.A. (1983) The Dilemma of American Immigration: Beyond the Golden Door. Transaction Publishers.

Campbell, S. (2014) "Does it Matter Why Immigrants Came Here? Original Motives, the Labour Market, and National Identity in the UK", Department of Quantitative Social Science, University of London, Working Paper No. 14-14. 
Chatterji, P., Alegria, M. and Takeuchi, D. (2011) "Psychiatric disorders and labor market outcomes: Evidence from the National Comorbidity SurveyReplication." Journal of Health Economics, 30(5): 858-868.

Chiquiar, D. and Hanson, G.H. (2005) "International Migration, Self-Selection, and the Distribution of Wages: Evidence from Mexico and the United States." Journal of Political Economy, 113(2): 239-281.

Chin, A. (2005) "Long-Run Labor Market Effects of Japanese American Internment during World War II on Working-Age Male Internees." Journal of Labor Economics 23(3): 491-525.

Chiswick, B.R. (1999) “Are Immigrants Favorably Self-Selected?" The American Economic Review, 89(2): 181-185.

Clark, K., and Lindley, J. (2009) "Immigrant Assimilation Pre and Post Labour Market Entry: Evidence from the UK Labour Force Survey." Journal of Population Economics, 22(1): 175-198.

Collyer, M. and Kulasinghe, D. (2010) "Review of Information on Return Conditions of Origin for Asylum Seekers in the UK." Report prepared for the Independent Advisory Group on Country Information.

Cortes, K.E. (2004) "Are Refugees Different from Economic Immigrants? Some Empirical Evidence on the Heterogeneity of Immigrant Groups in the United States." The Review of Economics and Statistics, 86(2): 465-480.

Constant, A. and Zimmermann, K. (2005) "Legal Status at Entry, Economic Performance, and Self-employment Proclivity: A Bi-national Study of Immigrants." IZA Discussion Paper 1910.

Delacrétaz, D. Kominers, S.D. and Teytelboym, A. (2016) "Refugee Resettlement", mimeo.

Drinkwater, S., Eade, J., and Garapich, M. (2009) "Poles Apart? EU Enlargement and the Labour Market Outcomes of Immigrants in the United Kingdom." International Migration, 47(1): 161-190.

Dustmann, C. and Fabbri, F. (2003) "Language Proficiency and Labour Market Performance of Immigrants in the UK." Economic Journal, 113(489): 695-717.

Dustmann, C., Fasani, F., Frattini, T., Minale, L. and Schönberg, U. (2017) "On the Economics and Politics of Refugee Migration." Economic Policy, 32(9): 497550.

Fernández-Huertas Moraga, J. and Rapoport, H. (2014) "Tradable RefugeeAdmission Quotas and EU Asylum Policy.” CESifo working paper no. 5072.

Fransen, S., Ruiz, I. and Vargas-Silva, C. (2017) "Return Migration and Economic Outcomes in the Conflict Context." World Development, 95: 196-210.

Frijters, P., Johnston, D.W. and Shields, M.A. (2010) "Mental Health and Labour Market Participation: Evidence from IV Panel Data Models." IZA Working Paper, 4883.

Gibney, M.J. (2008) "Asylum and the Expansion of Deportation in the United Kingdom." Government and Opposition, 43(2): 146-167.

Giuntella, O. Kone, Z.L., Ruiz, I. and Vargas-Silva, C. (2018) "Reason for Immigration and Immigrants' Health." Public Health, forthcoming.

Gower, M. (2016) "Should Asylum Seekers Have Unrestricted Rights to Work in the UK?" Briefing Paper, 1908. House of Commons Library.

Hainmueller. J., Hangartner, D. and D. Lawrence (2016) "When lives are put on hold: Lengthy asylum processes decrease employment among refugees." Science Advances, 2(8). 
Home Office (2015) "Syrian Vulnerable Person Resettlement (VPR) Programme. Guidance for Local Authorities and Partners" Home Office: London.

Home Office (2017) “Immigration Statistics: Asylum Tables Q4 2016.”Home Office: London.

House of Lords (2012) "Asylum Seekers" in Lords Lansard, Column WA107, July 2002.

Kausar, R. and Drinkwater, S. "A comparison of earnings and occupational attainment of refugees and asylum seekers and economic immigrants in the UK." Department of Economics, University of Surrey, 08/10.

Lindley, J.K. (2000) "Economic Assimilation and the Labour Market Performance of British Refugees and Economic Migrants" Research Paper Series Globalisation and Labour Markets Programme, 2002/06.

Lochmann, A., Rapoport, H. and Speciale, B. (2017) "The Effect of Language Training on Immigrants' Economic Integration - Empirical Evidence from France" CESifo Working Paper No. 6460.

Lubotsky, D.H. (2007) "Chutes or Ladders? A Longitudinal Analysis of Immigrant Earnings" Journal of Political Economy, 115(5): 820-867.

Nordic Economic Policy Review (2017). Copenhagen: Nordisk Ministerråd.

Oster, E. (2017) "Unobservable Selection and Coefficient Stability: Theory and Evidence" Journal of Business \& Economic Statistics, DOI: $10.1080 / 07350015.2016 .1227711$.

Ruiz, I. and Vargas-Silva, C. (2017) “Are Refugees' Labour Market Outcomes Different from Those of other Migrants? Evidence from the United Kingdom in the 2005 - 2007 Period" Population, Space and Place, 23(6).

Sarvimäki, M. (2017) "Labor Market Integration of Refugees in Finland" in Nordic Economic Policy Review, Copenhagen: Nordisk Ministerråd.

Sarvimäki, M. and Hämäläinen, K. (2016) "Integrating Immigrants: The Impact of Restructuring Active Labor Market Programs." Journal of Labor Economics (34)2: 479-508.

Schultz-Nielsen, M.L. (2017) "Labour Market Integration of Refugees in Denmark" in Nordic Economic Policy Review, Copenhagen: Nordisk Ministerråd.

Turner, S.W., Bowie, C., Dunn, G., Shapo, L., Yule, W. (2003) "Mental health of Kosovan Albanian refugees in the UK." The British Journal of Psychiatry 182(5): 444-448.

United Nations High Commission for Refugees (2016) "Global Trends: Forced Displacement 2015." UNHCR: Geneva.

Van Hear, N. (2006) “'I Went as Far as my Money would Take Me': Conflict, Forced Migration and Class" Centre on Migration, Policy and Society, Working Paper No. 6.

Vargas-Silva, C. (2017) "Remittances to and from the Displaced." Journal of Development Studies, 53(11): 1825-1848.

Warfa, N., Bhui, K., Craig, T., Curtis, S., Mohamud, S., Stansfeld, S., McCrone, P., Thornicroft, G. (2006) "Post-migration geographical mobility, mental health and health service utilisation among Somali refugees in the UK: A qualitative study" Health \& Place 12.4: 503-515.

Webber, D.J., Page, D., Veliziotis, M. and Johnson, S. (2015) "Does poor health affect employment transitions?" Joseph Rowntree Foundation Report. 


\section{Appendix}

Table A1 - Description of all variables included in the estimation.

\begin{tabular}{|c|c|}
\hline Variable & Definition \\
\hline In employment & $\begin{array}{l}\text { Dummy variable equal to one if the person is employment. Includes } \\
\text { those who are employees, those on a government scheme and those } \\
\text { who are self-employed. }\end{array}$ \\
\hline Weekly earnings & $\begin{array}{l}\text { Gross weekly pay in main job. Applies to all respondents who are } \\
\text { employees and those on a government scheme. }\end{array}$ \\
\hline Hourly salary & $\begin{array}{l}\text { Average gross hourly pay. Applies to all respondents who are } \\
\text { employees and those on a government scheme. }\end{array}$ \\
\hline Hours worked & $\begin{array}{l}\text { Total actual hours worked including overtime. Includes all } \\
\text { respondents who worked in the reference week. }\end{array}$ \\
\hline Female & Equal to one for women, zero otherwise. \\
\hline Work & $\begin{array}{l}\text { Equal to one if the individual reported coming to the UK in order to } \\
\text { work, zero otherwise. }\end{array}$ \\
\hline Study & $\begin{array}{l}\text { Equal to one if the individual reported coming to the UK in order to } \\
\text { study, zero otherwise. }\end{array}$ \\
\hline Family & $\begin{array}{l}\text { Equal to one if the individual reported coming to the UK for family } \\
\text { reasons (e.g. join spouse, as minor dependent), zero otherwise. }\end{array}$ \\
\hline Asylum & $\begin{array}{l}\text { Equal to one if the individual reported coming to the UK in order to } \\
\text { claim asylum, zero otherwise. }\end{array}$ \\
\hline Other & $\begin{array}{l}\text { Equal to one if the individual reported coming to the UK for reasons } \\
\text { other than work, study, family or asylum, zero otherwise. }\end{array}$ \\
\hline Age & Age in years. Estimations include a quartic on age. \\
\hline Married & Equal to one for those who are married, zero otherwise. \\
\hline Edu Med & $\begin{array}{l}\text { Equal to one for those who left full time education between age } 18 \\
\text { and } 20 \text {, zero otherwise. }\end{array}$ \\
\hline Edu Low & $\begin{array}{l}\text { Equal to one for those who left full time education before age } 18 \text {, } \\
\text { zero otherwise. }\end{array}$ \\
\hline Health problem & $\begin{array}{l}\text { Equal to one for those who reported a health problem lasting } 12 \\
\text { months or longer, zero otherwise. }\end{array}$ \\
\hline UK national & $\begin{array}{l}\text { Equal to one for those who are UK nationals regardless of country of } \\
\text { birth, zero otherwise. If the individual is a dual national, then UK } \\
\text { nationality is the one recorded. }\end{array}$ \\
\hline Time UK & $\begin{array}{l}\text { Number of years of residence in the UK. Set to zero for natives. } \\
\text { Some of the estimations include dummies for numbers of years } \\
\text { grouped in three year cohorts (i.e. } 4-6,7-9 \text {, etc.) }\end{array}$ \\
\hline Muslim & Equal to one if the individual is Muslim, zero otherwise. \\
\hline Other variables & $\begin{array}{l}\text { The estimations also include local area fixed effects and dummies } \\
\text { for year, quarter and, in some cases, region or country of origin. }\end{array}$ \\
\hline
\end{tabular}


Table A 2 - Results for key control variables (see Tables 6 and 7, columns 5 and 10).

\begin{tabular}{|c|c|c|c|c|}
\hline & In employment & Weekly earnings & Hourly salary & Hours worked \\
\hline \multirow{2}{*}{ Female } & $-0.1009 * * *$ & $-0.5149 * * *$ & $-0.2063 * * *$ & $-0.3227 * * *$ \\
\hline & $(0.0021)$ & $(0.0070)$ & $(0.0046)$ & $(0.0036)$ \\
\hline \multirow{2}{*}{ Age } & $0.4728 * * *$ & $0.7734 * * *$ & $0.3212 * * *$ & $0.4060 * * *$ \\
\hline & $(0.0180)$ & $(0.0380)$ & $(0.0237)$ & $(0.0246)$ \\
\hline \multirow{2}{*}{ Married } & $0.0580 * * *$ & $-0.0455 * * *$ & $0.0893 * * *$ & $-0.0394 * * *$ \\
\hline & $(0.0030)$ & $(0.0042)$ & $(0.0030)$ & $(0.0023)$ \\
\hline \multirow{2}{*}{ Edu Med } & $-0.0190 * * *$ & $-0.3025 * * *$ & $-0.2847 * * *$ & $-0.0384 * * *$ \\
\hline & $(0.0022)$ & $(0.0053)$ & $(0.0041)$ & $(0.0029)$ \\
\hline \multirow{2}{*}{ Edu Low } & $-0.0992 * * *$ & $-0.5236 * * *$ & $-0.4909 * * *$ & $-0.0572 * * *$ \\
\hline & $(0.0041)$ & $(0.0059)$ & $(0.0042)$ & $(0.0030)$ \\
\hline \multirow{2}{*}{ Health Problem } & $-0.1900 * * *$ & $-0.0876^{* * *}$ & $-0.0581 * * *$ & $-0.0447 * * *$ \\
\hline & $(0.0059)$ & $(0.0038)$ & $(0.0027)$ & $(0.0027)$ \\
\hline \multirow{2}{*}{ UK National } & $0.0269 * * *$ & $0.0547 * * *$ & $0.0504 * * *$ & $0.0102 * *$ \\
\hline & $(0.0039)$ & $(0.0079)$ & $(0.0063)$ & $(0.0046)$ \\
\hline \multirow{2}{*}{ Time UK } & $0.0026 * * *$ & $0.0095 * * *$ & $0.0083 * * *$ & $0.0018 * * *$ \\
\hline & $(0.0002)$ & $(0.0005)$ & $(0.0004)$ & $(0.0003)$ \\
\hline \multirow{2}{*}{ Muslim } & $-0.1811 * * *$ & $-0.3226 * * *$ & $-0.1757 * * *$ & $-0.1313 * * *$ \\
\hline & $(0.0071)$ & $(0.0185)$ & $(0.0128)$ & $(0.0092)$ \\
\hline Observations & 317,838 & 170,108 & 169,097 & 216,822 \\
\hline \multirow{2}{*}{$\begin{array}{l}\text { Controls } \\
\text { LA FE }\end{array}$} & $X$ & $X$ & $\mathrm{X}$ & $X$ \\
\hline & $X$ & $X$ & $X$ & $X$ \\
\hline \multicolumn{5}{|c|}{$\begin{array}{l}\text { Note: these are the coefficients for the main control variables included in the } \\
\text { estimations presented in Tables } 6 \text { and } 7 \text { of the paper with standard errors in } \\
\text { parenthesis. In addition to these variables the analysis controlled for local authority, } \\
\text { year and quarter. Also, age is included as a quartic in the estimation, but only first } \\
\text { coefficient is shown in the table. ***indicates significant at } 1 \% \text { level. }\end{array}$} \\
\hline
\end{tabular}


Table A3 - Baseline results with alternative ways of identifying refugees based on country of origin

\begin{tabular}{|c|c|c|}
\hline Dependent variable & $\begin{array}{c}\text { Share of refugees } \\
\text { (1) }\end{array}$ & $\begin{array}{l}\text { Share of all migrants } \\
\text { (2) }\end{array}$ \\
\hline In employment & $\begin{array}{c}-1.1674 * * * \\
(0.1202)\end{array}$ & $\begin{array}{c}-0.2155 * * * \\
(0.0220)\end{array}$ \\
\hline Observations & 37,688 & 37,589 \\
\hline Weekly earnings & $\begin{array}{l}-1.9810 * * * \\
(0.4205)\end{array}$ & $\begin{array}{c}-0.5595 * * * \\
(0.0655)\end{array}$ \\
\hline Observations & 18,271 & 18,228 \\
\hline Hourly salary & $\begin{array}{c}-1.1166 * * * \\
(0.3137)\end{array}$ & $\begin{array}{c}-0.3360 * * * \\
(0.0467)\end{array}$ \\
\hline Observations & 18,149 & 18,106 \\
\hline Hours worked & $\begin{array}{c}-0.6365 * * * \\
(0.1786)\end{array}$ & $\begin{array}{c}-0.1917 * * * \\
(0.0324)\end{array}$ \\
\hline Observations & 24,605 & 24,550 \\
\hline Controls & $\mathrm{X}$ & $\mathrm{X}$ \\
\hline LA FE & $\mathrm{X}$ & $\mathrm{X}$ \\
\hline
\end{tabular}

Note: the table reports the coefficients of the refugee variable with standard errors in parenthesis. Weekly earnings, hourly salary and weekly hours worked are included in logs in the estimation. Controls include gender, age (a quartic), marital status, education, religion, health status and UK nationality. ***indicates significant at $1 \%$ level. 
Table A4 - Robustness checks for unobservable bias and stability of asylum coefficient

\begin{tabular}{|c|c|}
\hline Dependent variable & Bounds for Asylum coefficient \\
\hline In employment & $(-0.1850,-0.1828)$ \\
\hline Weekly earnings & $(-0.8206,-0.7584)$ \\
\hline Hourly salary & $(-0.6534,-0.5905)$ \\
\hline Hours worked & $(-0.1811,-0.1703)$ \\
\hline
\end{tabular}


Figure 1 - Applications and grants of asylum in the UK.

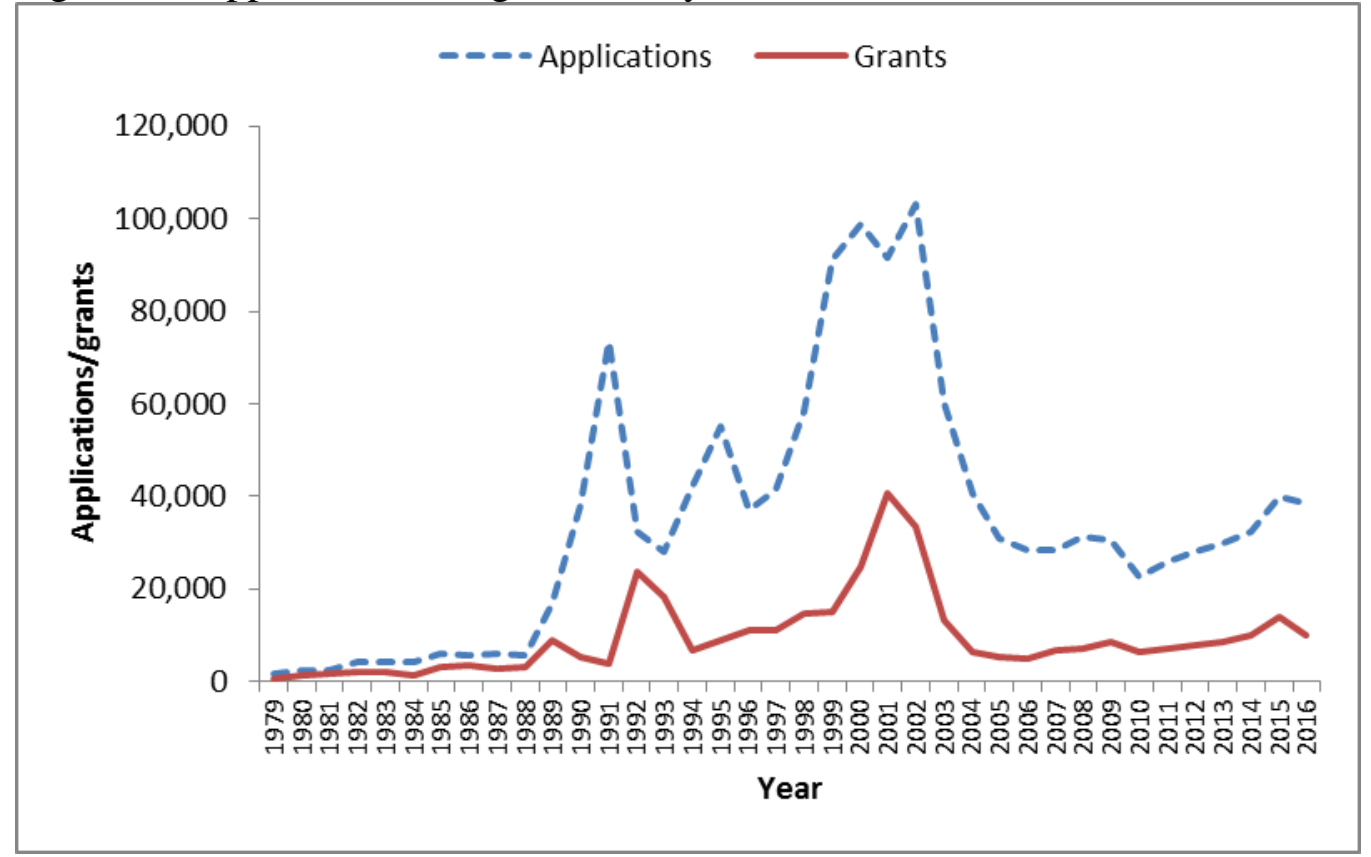

Notes: source is Home Office (2017). Grants of asylum include similar grants of protection such as humanitarian protection. Includes main applicants and dependants. 
Figure 2 - Labour market outcome gaps by time since arrival to the UK.
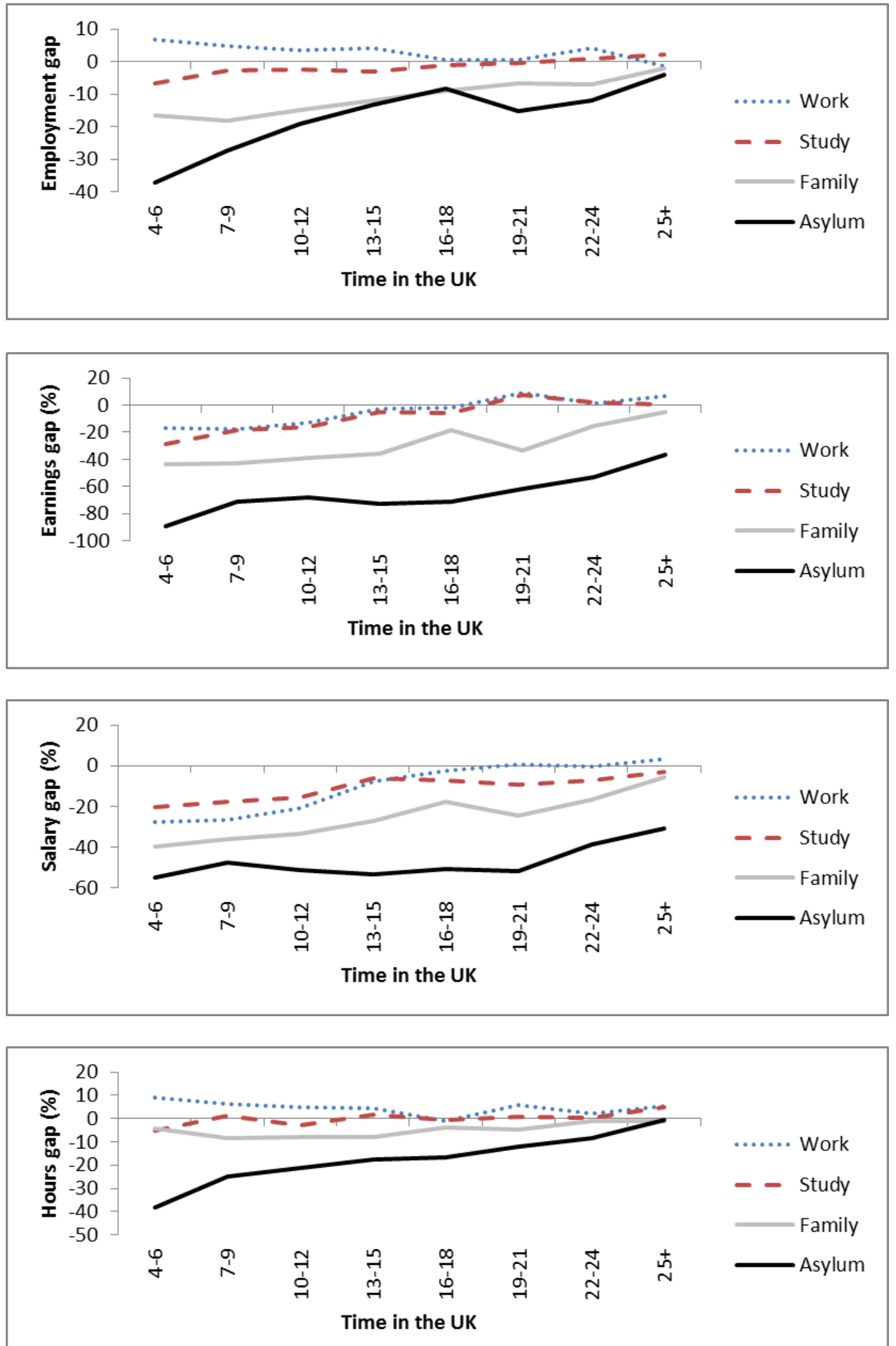

Notes: the chart plots the time coefficients from separate regressions which include natives and those who came for a given reason. See Equation (4) in the paper for details. 
Table 1 - Main reason for coming to UK

\begin{tabular}{lcc}
\hline \multirow{2}{*}{ Reason } & Share & Observations \\
& $(1)$ & $(2)$ \\
\hline Work & $25.1 \%$ & 9,592 \\
Study & $12.7 \%$ & 4,853 \\
Family & $45.8 \%$ & 17,499 \\
Asylum & $6.2 \%$ & 2,360 \\
Other & $10.2 \%$ & 3,900 \\
Total foreign-born & $100 \%$ & 38,204 \\
\hline
\end{tabular}


Table 2 - Main countries of origin of refugees and other migrants (\% share of category).

\begin{tabular}{cccccc}
\hline \multicolumn{2}{c}{ LFS refugees } & \multicolumn{2}{c}{ LFS non-refugees } & \multicolumn{2}{c}{ Home Office refugees } \\
Country & Share & Country & Share & Country & Share \\
$(1)$ & $(2)$ & $(3)$ & $(4)$ & $(5)$ & $(6)$ \\
\hline Somalia & $13 \%$ & India & $10 \%$ & Iraq & $10 \%$ \\
Afghanistan & $10 \%$ & Poland & $8 \%$ & Somalia & $8 \%$ \\
Sri Lanka & $9 \%$ & Pakistan & $8 \%$ & Afghanistan & $8 \%$ \\
Iraq & $8 \%$ & Germany & $5 \%$ & Iran & $6 \%$ \\
Zimbabwe & $6 \%$ & Ireland & $5 \%$ & Zimbabwe & $6 \%$ \\
\hline
\end{tabular}

Notes: LFS data for all those who arrived in the UK before 2007. Home Office data are for all those who were granted protection between 2001 and 2006 (main applicants). 
Table 3 - Descriptive statistics of main dependent variables (means).

\begin{tabular}{|c|c|c|c|c|}
\hline & In employment (yes =1) & Weekly earnings $(£)$ & Hourly salary (£) & Hours worked (weekly) \\
\hline Women & 0.73 & 393 & 12.37 & 27.67 \\
\hline Men & 0.82 & 630 & 15.70 & 38.36 \\
\hline \multicolumn{5}{|c|}{ (B) Reason for migration: Work } \\
\hline All & 0.86 & 591 & 15.02 & 36.08 \\
\hline Women & 0.82 & 486 & 13.63 & 30.52 \\
\hline Men & 0.90 & 677 & 16.15 & 39.89 \\
\hline Women & 0.77 & 525 & 15.50 & 29.28 \\
\hline Men & 0.87 & 709 & 17.80 & 38.74 \\
\hline \multicolumn{5}{|c|}{ (D) Reason for migration: Family } \\
\hline All & 0.66 & 467 & 13.29 & 31.70 \\
\hline Women & 0.57 & 390 & 12.35 & 27.47 \\
\hline Men & 0.81 & 576 & 14.60 & 36.86 \\
\hline \multicolumn{5}{|c|}{ (F) Reason for migration: Other } \\
\hline All & 0.74 & 496 & 13.76 & 32.81 \\
\hline Women & 0.68 & 410 & 12.63 & 28.00 \\
\hline Men & 0.81 & 604 & 15.15 & 37.89 \\
\hline
\end{tabular}


Table 4 - Descriptive statistics of control variables (means)

\begin{tabular}{|c|c|c|c|c|c|c|}
\hline \multirow{2}{*}{ Variable } & \multirow{2}{*}{ UK born } & \multicolumn{5}{|c|}{ Foreign-born: reason for migration } \\
\hline & & Work & Study & Family & Asylum & Other \\
\hline Female & 0.52 & 0.43 & 0.51 & 0.63 & 0.45 & 0.55 \\
\hline Age (years) & 42.47 & 41.30 & 39.99 & 42.83 & 40.97 & 44.00 \\
\hline Married & 0.55 & 0.70 & 0.67 & 0.72 & 0.66 & 0.64 \\
\hline Edu med & 0.29 & 0.38 & 0.26 & 0.33 & 0.36 & 0.40 \\
\hline Edu low & 0.48 & 0.15 & 0.06 & 0.32 & 0.33 & 0.25 \\
\hline Muslim & 0.01 & 0.08 & 0.16 & 0.27 & 0.48 & 0.15 \\
\hline Health problem & 0.33 & 0.21 & 0.19 & 0.32 & 0.37 & 0.33 \\
\hline UK national & 0.96 & 0.28 & 0.42 & 0.69 & 0.62 & 0.52 \\
\hline Time UK (years) & 0.00 & 14.46 & 17.83 & 26.94 & 16.11 & 22.26 \\
\hline Time UK 4-6 years & - & 0.12 & 0.06 & 0.04 & 0.03 & 0.04 \\
\hline Time UK 7-9 years & - & 0.21 & 0.14 & 0.08 & 0.12 & 0.10 \\
\hline Time UK $10-12$ years & - & 0.24 & 0.20 & 0.11 & 0.22 & 0.15 \\
\hline Time UK $13-15$ years & - & 0.13 & 0.14 & 0.08 & 0.22 & 0.12 \\
\hline Time UK $16-18$ years & - & 0.07 & 0.10 & 0.07 & 0.15 & 0.10 \\
\hline Time UK 19-21 years & - & 0.04 & 0.08 & 0.06 & 0.09 & 0.06 \\
\hline Time UK 22-24 years & - & 0.04 & 0.06 & 0.06 & 0.07 & 0.06 \\
\hline Africa & - & 0.14 & 0.26 & 0.17 & 0.43 & 0.30 \\
\hline Americas & - & 0.05 & 0.08 & 0.10 & 0.01 & 0.10 \\
\hline Asia & - & 0.24 & 0.35 & 0.44 & 0.38 & 0.21 \\
\hline Europe & - & 0.54 & 0.30 & 0.26 & 0.10 & 0.31 \\
\hline Observations & 279,634 & 9,592 & 4,853 & 17,499 & 2,360 & 3,900 \\
\hline
\end{tabular}

Notes: see Appendix 1 for the definition of all variables. 
Table 5 - Descriptive statistics of main dependent variables for 2010 and 2016 only.

\section{Migrated for:}

Variable

Asylum Other reasons

(1) (2)

\begin{tabular}{lcc}
\hline & \multicolumn{2}{c}{$(\mathrm{A}) 2010$} \\
\hline In employment (yes =1) & 0.44 & 0.74 \\
Weekly earnings (£) & 332 & 503 \\
Hourly salary (£) & 9.67 & 13.48 \\
Hours worked (weekly) & 32.25 & 33.46 \\
\hline & \multicolumn{2}{c}{ (B) 2016 } \\
\hline In employment (yes =1) & 0.64 & 0.75 \\
Weekly earnings (£) & 294 & 571 \\
Hourly salary (£) & 8.90 & 15.17 \\
Hours worked (weekly) & 32.35 & 33.94 \\
\hline
\end{tabular}

Notes: Weekly earnings and hourly salary only available for those who are employees or in government schemes. 
Table 6 -Employment and weekly earnings: UK-born versus foreign-born.

\begin{tabular}{|c|c|c|c|c|c|c|c|c|c|c|}
\hline \multirow{2}{*}{$\begin{array}{l}\text { Reason for migration } \\
\text { (reference is UK-born) }\end{array}$} & \multicolumn{5}{|c|}{ Dependent variable: In employment } & \multicolumn{5}{|c|}{ Dependent variable: Weekly earnings } \\
\hline & (1) & $(2)$ & (3) & (4) & (5) & (6) & (7) & (8) & (9) & $(10)$ \\
\hline & $0.0920 * * *$ & $-0.0319 * * *$ & $-0.0252 * * *$ & $0.0044 * * *$ & -0.0015 & $0.1469 * * *$ & $-0.2168 * * *$ & $-0.1410 * * *$ & $-0.0557 * * *$ & $-0.2116^{* * *}$ \\
\hline Work & $(0.0035)$ & $(0.0041)$ & $(0.0058)$ & $(0.0040)$ & $(0.0058)$ & $(0.0101)$ & $(0.0105)$ & $(0.0128)$ & $(0.0138)$ & $(0.0148)$ \\
\hline Study & $\begin{array}{c}0.0407 * * * \\
(0.0055)\end{array}$ & $\begin{array}{c}-0.0807 * * * \\
(0.0064)\end{array}$ & $\begin{array}{c}-0.0206^{* * *} * \\
(0.0075)\end{array}$ & $\begin{array}{c}0.0026 \\
(0.0061)\end{array}$ & $\begin{array}{c}-0.0513 * * * \\
(0.0070)\end{array}$ & $\begin{array}{c}0.2089 * * * \\
(0.0149)\end{array}$ & $\begin{array}{c}-0.2123 * * * \\
(0.0158)\end{array}$ & $\begin{array}{c}-0.1290 * * * \\
(0.0222)\end{array}$ & $\begin{array}{c}-0.0493 * * * \\
(0.0179)\end{array}$ & $\begin{array}{c}-0.2387 * * * \\
(0.0214)\end{array}$ \\
\hline Family & $\begin{array}{c}-0.1152 * * * \\
(0.0037)\end{array}$ & $\begin{array}{c}-0.1713 * * * \\
(0.0061)\end{array}$ & $\begin{array}{c}-0.1646 * * * \\
(0.0010)\end{array}$ & $\begin{array}{c}-0.0728 * * * \\
(0.0040)\end{array}$ & $\begin{array}{c}-0.1471 * * * \\
(0.0075)\end{array}$ & $\begin{array}{c}-0.1117 * * * \\
(0.0093)\end{array}$ & $\begin{array}{c}-0.4374 * * * \\
(0.1484)\end{array}$ & $\begin{array}{c}-0.4263 * * * \\
(0.0197)\end{array}$ & $\begin{array}{c}-0.1610 * * * \\
(0.0104)\end{array}$ & $\begin{array}{c}-0.4351 * * * \\
(0.0175)\end{array}$ \\
\hline Asylum & $\begin{array}{c}-0.2170 * * * \\
(0.0102)\end{array}$ & $\begin{array}{c}-0.2154 * * * \\
(0.0101)\end{array}$ & $\begin{array}{c}-0.2633 * * * \\
(0.0158)\end{array}$ & $\begin{array}{c}-0.1366^{* * * *} \\
(0.0126)\end{array}$ & $\begin{array}{c}-0.1850 * * * \\
(0.0136)\end{array}$ & $\begin{array}{c}-0.5027 * * * \\
(0.0263)\end{array}$ & $\begin{array}{c}-0.7174 * * * \\
(0.0267)\end{array}$ & $\begin{array}{c}-0.8736 * * * \\
(0.0332)\end{array}$ & $\begin{array}{c}-0.5810 * * * \\
(0.0278)\end{array}$ & $\begin{array}{c}-0.7584 * * * \\
(0.0307)\end{array}$ \\
\hline Other & $\begin{array}{c}-0.0406 * * * \\
(0.0070)\end{array}$ & $\begin{array}{c}-0.1196 * * * \\
(0.0076)\end{array}$ & $\begin{array}{c}-0.0969 * * * \\
(0.0100)\end{array}$ & $\begin{array}{c}-0.0283 * * * \\
(0.0071)\end{array}$ & $\begin{array}{c}-0.0914 * * * \\
(0.0089)\end{array}$ & $\begin{array}{c}-0.0422 * * \\
(0.0182)\end{array}$ & $\begin{array}{c}-0.3703 * * * \\
(0.0190)\end{array}$ & $\begin{array}{c}-0.3834 * * * \\
(0.0240)\end{array}$ & $\begin{array}{c}-0.1749 * * * \\
(0.0180)\end{array}$ & $\begin{array}{c}-0.3985^{* * *} \\
(0.0214)\end{array}$ \\
\hline Observations & 317,838 & 317,838 & 317,838 & 317,838 & 317,838 & 170,108 & 170,108 & 170,108 & 170,108 & 170,108 \\
\hline
\end{tabular}

Control age and gender

only

Full controls, excludes

time in the UK

Full controls

LA FE

Notes: Weekly earnings are included in logs in the estimation.

$\mathrm{X}$
$\mathrm{X}$

$\mathrm{X}$

$\mathrm{X}$

$\mathrm{X}$
$\mathrm{X}$

$\mathrm{X}$

$\begin{array}{lll} & & \\ X & X & X\end{array}$

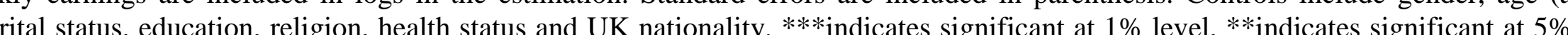
level. 
Table 7 - Hourly salary and hours worked: UK-born versus foreign-born.

\begin{tabular}{|c|c|c|c|c|c|c|c|c|c|c|}
\hline \multirow{2}{*}{$\begin{array}{l}\text { Reason for migration } \\
\text { (reference is UK-born) }\end{array}$} & \multicolumn{5}{|c|}{ Dependent variable: Hourly salary } & \multicolumn{5}{|c|}{ Dependent variable: Hours worked } \\
\hline & (1) & (2) & (3) & (4) & $(5)$ & $(6)$ & (7) & $(8)$ & $(9)$ & $(10)$ \\
\hline Work & $\begin{array}{c}0.0394 * * * \\
(0.0085)\end{array}$ & $\begin{array}{c}-0.2784 * * * \\
(0.0087)\end{array}$ & $\begin{array}{c}-0.1925^{* * * *} \\
(0.0107)\end{array}$ & $\begin{array}{c}-0.1345^{* * *} \\
(0.0118)\end{array}$ & $\begin{array}{c}-0.2716 * * * \\
(0.0119)\end{array}$ & $\begin{array}{c}0.0977 * * * \\
(0.0050)\end{array}$ & $\begin{array}{c}0.0287 * * * \\
(0.0060)\end{array}$ & $\begin{array}{c}0.0252 * * * \\
(0.0064)\end{array}$ & $\begin{array}{c}0.0641 * * * \\
(0.0061)\end{array}$ & $\begin{array}{c}0.0337 * * * \\
(0.0076)\end{array}$ \\
\hline Study & $\begin{array}{c}0.1810^{* * * *} \\
(0.0115)\end{array}$ & $\begin{array}{c}-0.2132 * * * \\
(0.0122)\end{array}$ & $\begin{array}{c}-0.1115^{* * *} \\
(0.0188)\end{array}$ & $\begin{array}{c}-0.0727 * * * \\
(0.0144)\end{array}$ & $\begin{array}{c}-0.2394 * * * \\
(0.0174)\end{array}$ & $\begin{array}{c}0.0342 * * * \\
(0.0083)\end{array}$ & $\begin{array}{l}-0.0169 * \\
(0.0094)\end{array}$ & $\begin{array}{c}-0.0232 * * * \\
(0.0097)\end{array}$ & $\begin{array}{c}0.0249 * * * \\
(0.0085)\end{array}$ & $\begin{array}{c}0.0121 \\
(0.0104)\end{array}$ \\
\hline Family & $\begin{array}{c}-0.0603 * * * \\
(0.0069)\end{array}$ & $\begin{array}{c}-0.3902 * * * \\
(0.0111)\end{array}$ & $\begin{array}{c}-0.3464 * * * \\
(0.0144)\end{array}$ & $\begin{array}{c}-0.1466 * * * \\
(0.0083)\end{array}$ & $\begin{array}{c}-0.3876 * * * \\
(0.0134)\end{array}$ & $\begin{array}{c}-0.0538 * * * \\
(0.0052)\end{array}$ & $\begin{array}{c}-0.0738 * * * \\
(0.0091)\end{array}$ & $\begin{array}{c}-0.1009 * * * \\
(0.0105)\end{array}$ & $\begin{array}{c}-0.0164 * * * \\
(0.0058)\end{array}$ & $\begin{array}{c}-0.0689 * * * \\
(0.0102)\end{array}$ \\
\hline Asylum & $\begin{array}{c}-0.3399 * * * \\
(0.0171)\end{array}$ & $\begin{array}{c}-0.5507 * * * \\
(0.0183)\end{array}$ & $\begin{array}{c}-0.6400 * * * \\
(0.0250)\end{array}$ & $\begin{array}{c}-0.4346 * * * \\
(0.0223)\end{array}$ & $\begin{array}{c}-0.5905 * * * \\
(0.0245)\end{array}$ & $\begin{array}{c}-0.1302 * * * \\
(0.0151)\end{array}$ & $\begin{array}{c}-0.1722 * * * \\
(0.0153)\end{array}$ & $\begin{array}{c}-0.2347 * * * \\
(0.0140)\end{array}$ & $\begin{array}{c}-0.1362 * * * \\
(0.0133)\end{array}$ & $\begin{array}{c}-0.1703 * * * \\
(0.0141)\end{array}$ \\
\hline Other & $\begin{array}{l}-0.0287 \\
(0.0138)\end{array}$ & $\begin{array}{c}-0.3438 * * * \\
(0.0148)\end{array}$ & $\begin{array}{c}-0.3368 * * * \\
(0.0188)\end{array}$ & $\begin{array}{c}-0.1737 * * * \\
(0.0142)\end{array}$ & $\begin{array}{c}-0.3704 * * * \\
(0.0167)\end{array}$ & $\begin{array}{l}-0.0129 \\
(0.0104)\end{array}$ & $\begin{array}{c}-0.0506 * * * \\
(0.0113)\end{array}$ & $\begin{array}{c}-0.0652 * * * \\
(0.0119)\end{array}$ & $\begin{array}{c}-0.0031^{* * *} \\
(0.0095)\end{array}$ & $\begin{array}{c}-0.0463 * * * \\
(0.0119)\end{array}$ \\
\hline Observations & 169,097 & 169,097 & 169,097 & 169,097 & 169,097 & 216,822 & 216,822 & 216,822 & 216,822 & 216,822 \\
\hline $\begin{array}{l}\text { Control age and gender } \\
\text { only }\end{array}$ & & & $X$ & & & & & $X$ & & \\
\hline $\begin{array}{l}\text { Full controls, excludes } \\
\text { time in the UK }\end{array}$ & & & & $\mathrm{X}$ & & & & & $\mathrm{X}$ & \\
\hline Full controls & & $\mathrm{X}$ & & & $X$ & & $X$ & & & $\mathrm{X}$ \\
\hline LA FE & & & $X$ & $\mathrm{X}$ & $\mathrm{X}$ & & & $\mathrm{X}$ & $X$ & $\mathrm{X}$ \\
\hline
\end{tabular}

Notes: Weekly earnings are included in logs in the estimation. Standard errors are included in parenthesis. Controls include gender, age (a quartic), marital status, education, religion, health status and UK nationality. ***indicates significant at $1 \%$ level, *indicates significant at $10 \%$ level. 
Table 8 - Main results by gender

\begin{tabular}{|c|c|c|c|c|c|c|c|c|}
\hline \multirow{2}{*}{$\begin{array}{l}\text { Reason for migration } \\
\text { (reference is UK-born) }\end{array}$} & \multicolumn{8}{|c|}{ Dependent variable } \\
\hline & \multicolumn{2}{|c|}{ In employment } & \multicolumn{2}{|c|}{ Weekly earnings } & \multicolumn{2}{|c|}{ Hourly salary } & \multicolumn{2}{|c|}{ Hours worked } \\
\hline & \multicolumn{8}{|c|}{ (A) Women } \\
\hline Work & $\begin{array}{c}0.0432 * * * \\
(0.0066)\end{array}$ & $\begin{array}{l}-0.0104 \\
(0.0082)\end{array}$ & $\begin{array}{c}0.0213 \\
(0.0178)\end{array}$ & $\begin{array}{c}-0.1111 * * * \\
(0.0194)\end{array}$ & $\begin{array}{c}-0.1062 * * * \\
(0.0136)\end{array}$ & $\begin{array}{c}-0.2323 * * * \\
(0.0142)\end{array}$ & $\begin{array}{l}0.1117 * * * \\
(0.0117)\end{array}$ & $\begin{array}{c}0.0904 * * * \\
(0.0140)\end{array}$ \\
\hline Study & $\begin{array}{l}-0.0147 \\
(0.0093)\end{array}$ & $\begin{array}{c}-0.0786 * * * \\
(0.0105)\end{array}$ & $\begin{array}{l}-0.0078 \\
(0.0225)\end{array}$ & $\begin{array}{c}-0.1717 * * * \\
(0.0270)\end{array}$ & $\begin{array}{c}-0.0509 * * * \\
(0.0156)\end{array}$ & $\begin{array}{c}-0.2071^{* * *} \\
(0.0195)\end{array}$ & $\begin{array}{l}0.0272^{*} \\
(0.0150)\end{array}$ & $\begin{array}{l}-0.0011 \\
(0.0168)\end{array}$ \\
\hline Family & $\begin{array}{c}-0.1001 * * * \\
(0.0055)\end{array}$ & $\begin{array}{c}-0.1837 * * * \\
(0.0098)\end{array}$ & $\begin{array}{c}-0.1635 * * * \\
(0.0137)\end{array}$ & $\begin{array}{c}-0.3876 * * * \\
(0.0242)\end{array}$ & $\begin{array}{c}-0.1507 * * * \\
(0.0098)\end{array}$ & $\begin{array}{c}-0.3641 * * * \\
(0.0179)\end{array}$ & $\begin{array}{l}-0.0093 \\
(0.0091)\end{array}$ & $\begin{array}{c}-0.0448 * * * \\
(0.0154)\end{array}$ \\
\hline Asylum & $\begin{array}{c}-0.1871 * * * \\
(0.0159)\end{array}$ & $\begin{array}{c}-0.2455^{* * *} \\
(0.0165)\end{array}$ & $\begin{array}{c}-0.4472 * * * \\
(0.0404)\end{array}$ & $\begin{array}{c}-0.6052 * * * \\
(0.0435)\end{array}$ & $\begin{array}{c}-0.3434 * * * \\
(0.0299)\end{array}$ & $\begin{array}{c}-0.4934 * * * \\
(0.0330)\end{array}$ & $\begin{array}{c}-0.1153 * * * \\
(0.0283)\end{array}$ & $\begin{array}{c}-0.1407 * * * \\
(0.0294)\end{array}$ \\
\hline Other & $\begin{array}{c}-0.0392 * * * \\
(0.0096)\end{array}$ & $\begin{array}{c}-0.1142 * * * \\
(0.0118)\end{array}$ & $\begin{array}{c}-0.1534 * * * \\
(0.0246)\end{array}$ & $\begin{array}{c}-0.3430 * * * \\
(0.0294)\end{array}$ & $\begin{array}{c}-0.1479 * * * \\
(0.0181)\end{array}$ & $\begin{array}{c}-0.3285^{* * *} * \\
(0.0221)\end{array}$ & $\begin{array}{l}-0.0029 \\
(0.0145)\end{array}$ & $\begin{array}{l}-0.0281 \\
(0.0175)\end{array}$ \\
\hline \multirow[t]{2}{*}{ Observations } & 167,297 & 167,297 & 90,207 & 90,207 & 89,797 & 89,797 & 104,327 & 104,327 \\
\hline & \multicolumn{8}{|c|}{ (B) Men } \\
\hline Work & $\begin{array}{c}0.0227 * * * \\
(0.0056)\end{array}$ & $\begin{array}{l}-0.0124 * \\
(0.0069)\end{array}$ & $\begin{array}{c}-0.1279 * * * \\
(0.0164)\end{array}$ & $\begin{array}{c}-0.3093 * * * \\
(0.0193)\end{array}$ & $\begin{array}{c}-0.1603 * * * \\
(0.0145)\end{array}$ & $\begin{array}{c}-0.3083 * * * \\
(0.0162)\end{array}$ & $\begin{array}{c}0.0239 * * * \\
(0.0065)\end{array}$ & $\begin{array}{c}-0.0161 * * * \\
(0.0085)\end{array}$ \\
\hline Study & $\begin{array}{l}-0.0050 \\
(0.0072)\end{array}$ & $\begin{array}{l}-0.0168^{*} \\
(0.0090)\end{array}$ & $\begin{array}{c}-0.0911 * * * \\
(0.0237)\end{array}$ & $\begin{array}{c}-0.3086 * * * \\
(0.0262)\end{array}$ & $\begin{array}{c}-0.0917 * * * \\
(0.0203)\end{array}$ & $\begin{array}{c}-0.2695 * * * \\
(0.0228)\end{array}$ & $\begin{array}{c}0.0191 * * \\
(0.0097)\end{array}$ & $\begin{array}{r}-0.0294 * * \\
(-0.0117)\end{array}$ \\
\hline Family & $\begin{array}{l}-0.0096^{*} \\
(0.0050)\end{array}$ & $\begin{array}{c}-0.0276 * * * \\
(0.0087)\end{array}$ & $\begin{array}{c}-0.1575 * * * \\
(0.0141)\end{array}$ & $\begin{array}{c}-0.4968 * * * \\
(0.0249)\end{array}$ & $\begin{array}{c}-0.1400 * * * \\
(0.0117)\end{array}$ & $\begin{array}{c}-0.4172 * * * \\
(0.0189)\end{array}$ & $\begin{array}{c}-0.0223 * * * \\
(0.0064)\end{array}$ & $\begin{array}{c}-0.0950 * * * \\
(0.0122)\end{array}$ \\
\hline Asylum & $\begin{array}{c}-0.1224 * * * \\
(0.0160)\end{array}$ & $\begin{array}{c}-0.1330 * * * \\
(0.0166)\end{array}$ & $\begin{array}{c}-0.6946 * * * \\
(0.0352)\end{array}$ & $\begin{array}{c}-0.8957 * * * \\
(0.0376)\end{array}$ & $\begin{array}{c}-0.4977 * * * \\
(0.0261)\end{array}$ & $\begin{array}{c}-0.6623 * * * \\
(0.0281)\end{array}$ & $\begin{array}{c}-0.1604 * * * \\
(0.0164)\end{array}$ & $\begin{array}{c}-0.2043 * * * \\
(0.0172)\end{array}$ \\
\hline Other & $\begin{array}{c}-0.0325 * * * \\
(0.0092)\end{array}$ & $\begin{array}{c}-0.0465 * * * \\
(0.0114)\end{array}$ & $\begin{array}{c}-0.2186 * * * \\
(0.0222)\end{array}$ & $\begin{array}{c}-0.4813 * * * \\
(0.0259)\end{array}$ & $\begin{array}{c}-0.2135 * * * \\
(0.0216)\end{array}$ & $\begin{array}{c}-0.4281 * * * \\
(0.0246)\end{array}$ & $\begin{array}{l}-0.0173 \\
(0.0127)\end{array}$ & $\begin{array}{c}-0.0734 * * * \\
(0.0145)\end{array}$ \\
\hline Observations & 150,541 & 150,541 & 79,901 & 79,901 & 79,300 & 79,300 & 112,495 & 112,495 \\
\hline $\begin{array}{l}\text { Full controls, excluding time } \\
\text { in the UK }\end{array}$ & $X$ & & $X$ & & $\mathrm{X}$ & & $\mathrm{X}$ & \\
\hline Full controls & & $X$ & & $\mathrm{X}$ & & $X$ & & $\mathrm{X}$ \\
\hline LA FE & $\mathrm{X}$ & $X$ & $X$ & $\mathrm{X}$ & $\mathrm{X}$ & $\mathrm{X}$ & $\mathrm{X}$ & $X$ \\
\hline
\end{tabular}

Notes: Weekly earnings are included in logs in the estimation Standard errors are included in parenthesis. Controls include gender, age (a quartic), marital status, education, religion, health status and UK nationality. ***indicates significant at $1 \%$ level, **indicates significant at $5 \%$ level, *indicates significant at $10 \%$ level. 
Table 9 -Labour market outcomes differences among migrants

\begin{tabular}{|c|c|c|c|c|c|c|c|c|}
\hline \multirow{2}{*}{$\begin{array}{l}\text { Reason for migration } \\
\text { (reference is work) }\end{array}$} & \multicolumn{8}{|c|}{ Dependent variable } \\
\hline & \multicolumn{2}{|c|}{ In employment } & \multicolumn{2}{|c|}{ Weekly earnings } & \multicolumn{2}{|c|}{ Hourly salary } & \multicolumn{2}{|c|}{ Hours worked } \\
\hline Study & $\begin{array}{c}-0.0324 * * * \\
(0.0062)\end{array}$ & $\begin{array}{c}-0.0133^{* *} \\
(0.0062)\end{array}$ & $\begin{array}{l}-0.0372^{*} \\
(0.0218)\end{array}$ & $\begin{array}{c}-0.0468 * * \\
(0.0185)\end{array}$ & $\begin{array}{c}0.0209 \\
(0.0176)\end{array}$ & $\begin{array}{c}-0.0012 \\
(0.0143)\end{array}$ & $\begin{array}{c}-0.0461 * * * \\
(0.0094)\end{array}$ & $\begin{array}{c}-0.0351 * * * \\
(0.0098)\end{array}$ \\
\hline Family & $\begin{array}{c}-0.1031 * * * \\
(0.0057)\end{array}$ & $\begin{array}{c}-0.0934 * * * \\
(0.0059)\end{array}$ & $\begin{array}{c}-0.2194 * * * \\
(0.0161)\end{array}$ & $\begin{array}{c}-0.2504 * * * \\
(0.0158)\end{array}$ & $\begin{array}{c}-0.1179 * * * \\
(0.0131)\end{array}$ & $\begin{array}{c}-0.1576 * * * \\
(0.0120)\end{array}$ & $\begin{array}{c}-0.1000 * * * \\
(0.0083)\end{array}$ & $\begin{array}{c}-0.0955^{* * *} * \\
(0.0089)\end{array}$ \\
\hline Asylum & $\begin{array}{c}-0.1716^{* * * *} \\
(0.0150)\end{array}$ & $\begin{array}{c}-0.1247 * * * * \\
(0.0158)\end{array}$ & $\begin{array}{c}-0.5035^{* * *} \\
(0.0331)\end{array}$ & $\begin{array}{c}-0.4310^{* * * *} \\
(0.0340)\end{array}$ & $\begin{array}{c}-0.3008 * * * \\
(0.0287)\end{array}$ & $\begin{array}{c}-0.2697 * * * \\
(0.0292)\end{array}$ & $\begin{array}{c}-0.1845 * * * \\
(0.0154)\end{array}$ & $\begin{array}{c}-0.1566 * * * \\
(0.0172)\end{array}$ \\
\hline Other & $\begin{array}{c}-0.0702 * * * \\
(0.0081)\end{array}$ & $\begin{array}{c}-0.0610^{* * * *} \\
(0.0078)\end{array}$ & $\begin{array}{c}-0.2138 * * * \\
(0.0216)\end{array}$ & $\begin{array}{c}-0.2359 * * * \\
(0.0205)\end{array}$ & $\begin{array}{c}-0.1301 * * * \\
(0.0176)\end{array}$ & $\begin{array}{c}-0.1579 * * * \\
(0.0161)\end{array}$ & $\begin{array}{c}-0.0807 * * * \\
(0.0112)\end{array}$ & $\begin{array}{c}-0.0765^{* * *} \\
(0.0116)\end{array}$ \\
\hline Observations & 38,204 & 38,204 & 18,501 & 18,501 & 18,378 & 18,378 & 24,935 & 24,935 \\
\hline Country of origin $\mathrm{c}$ & & $\mathrm{X}$ & & $\mathrm{X}$ & & $\mathrm{X}$ & & $\mathrm{X}$ \\
\hline Region of origin controls & $\mathrm{X}$ & & $\mathrm{X}$ & & $\mathrm{X}$ & & $\mathrm{X}$ & \\
\hline Other controls & $\mathrm{X}$ & $\mathrm{X}$ & $\mathrm{X}$ & $\mathrm{X}$ & $\mathrm{X}$ & $\mathrm{X}$ & $\mathrm{X}$ & $\mathrm{X}$ \\
\hline LA FE & $\mathrm{X}$ & $\mathrm{X}$ & $\mathrm{X}$ & $\mathrm{X}$ & $\mathrm{X}$ & $\mathrm{X}$ & $\mathrm{X}$ & $\mathrm{X}$ \\
\hline
\end{tabular}

Notes: Weekly earnings, hourly salary and hours worked are included in logs in the estimation. Other controls include gender, age (a quartic), marital status, education, religion, health status and UK nationality. Standard errors are included in parenthesis. ***indicates significant at $1 \%$ level, **indicates significant at 5\% level, *indicates significant at $10 \%$ level. 
Table 10 - Coefficients for the years in the UK dummies in the employment regression.

\begin{tabular}{lccccc}
\hline \multirow{2}{*}{ Years in the UK } & \multicolumn{4}{c}{ Reason for migration } \\
& Work & Study & Family & Asylum & Other \\
\hline $4-6$ & $0.0669 * * *$ & $-0.0658^{* *}$ & $-0.1650^{* * *}$ & $-0.3727 * * *$ & 0.0620 \\
& $(0.0104)$ & $(0.0269)$ & $(0.0194)$ & $(0.0537)$ & $(0.0532)$ \\
$7-9$ & $0.0468 * * *$ & $-0.0274 *$ & $-0.1829 * * *$ & $-0.2743 * * *$ & -0.0398 \\
& $(0.0071)$ & $(0.0162)$ & $(0.0133)$ & $(0.0276)$ & $(0.0319)$ \\
$10-12$ & $0.0341 * * *$ & $-0.0235^{*}$ & $-0.1495 * * *$ & $-0.1906 * * *$ & -0.0086 \\
& $(0.0069)$ & $(0.0122)$ & $(0.0108)$ & $(0.0265)$ & $(0.0289)$ \\
$13-15$ & $0.0402 * * *$ & $-0.0303 *$ & $-0.1205^{* * *}$ & $-0.1313 * * *$ & $-0.0798 * * *$ \\
& $(0.0087)$ & $(0.0173)$ & $(0.0124)$ & $(0.0212)$ & $(0.0305)$ \\
$16-18$ & 0.0049 & -0.0100 & $-0.0892 * * *$ & $-0.0837 * * *$ & -0.0223 \\
& $(0.0138)$ & $(0.0148)$ & $(0.0132)$ & $(0.0259)$ & $(0.0356)$ \\
$19-21$ & 0.0058 & -0.0044 & $-0.0671 * * *$ & $-0.1513 * * *$ & -0.0489 \\
& $(0.0208)$ & $(0.0177)$ & $(0.0130)$ & $(0.0354)$ & $(0.0439)$ \\
$22-24$ & $0.0400 * *$ & 0.0085 & $-0.0700^{* * *}$ & $-0.1187 * * *$ & $-0.0761 *$ \\
& $(0.0173)$ & $(0.0200)$ & $(0.0141)$ & $(0.0312)$ & $(0.0340)$ \\
$25+$ & -0.0139 & $0.0208^{*}$ & $-0.0216 * * *$ & $-0.0409 * * *$ & $-0.0898 * * *$ \\
& $(0.0105)$ & $(0.0120)$ & $(0.0050)$ & $(0.0242)$ & $(0.0143)$ \\
Observations & 289,226 & 284,487 & 297,133 & 281,994 & 282,124
\end{tabular}

\begin{tabular}{llllll} 
Full controls & $\mathrm{X}$ & $\mathrm{X}$ & $\mathrm{X}$ & $\mathrm{X}$ & $\mathrm{X}$ \\
LA FE & $\mathrm{X}$ & $\mathrm{X}$ & $\mathrm{X}$ & $\mathrm{X}$ & $\mathrm{X}$ \\
\hline
\end{tabular}

Notes: each regression includes natives and those who migrated for the particular reason. ***indicates significant at $1 \%$ level, $* *$ indicates significant at $5 \%$ level, *indicates significant at $10 \%$ level. 
Table 11 - Convergence in labour market outcomes between 2010 and 2016.

\begin{tabular}{|c|c|c|c|c|c|c|}
\hline \multirow{3}{*}{$\begin{array}{l}\text { Independent variable } \\
\text { D2016 }\end{array}$} & \multicolumn{6}{|c|}{ Dependent variable } \\
\hline & \multicolumn{3}{|c|}{ In employment } & \multicolumn{3}{|c|}{ Weekly earnings } \\
\hline & $0.0172 *$ & $0.0413 * * *$ & $0.0407 * * *$ & $0.1065 * * *$ & $0.0496 * *$ & $0.0736^{* * *}$ \\
\hline & $(0.0090)$ & $(0.0097)$ & $(0.0100)$ & $(0.0206)$ & $(0.0224)$ & $(0.0230)$ \\
\hline \multirow[t]{2}{*}{$\mathrm{R}$} & $-0.3030 * * *$ & $-0.1906 * * *$ & $-0.1884 * * *$ & $-0.2639 * * *$ & $-0.1430 *$ & $-0.1521 *$ \\
\hline & $(0.0268)$ & $(0.0299)$ & $(0.0295)$ & $(0.0716)$ & $(0.0750)$ & $(0.0789)$ \\
\hline \multirow[t]{2}{*}{$\mathrm{D} 2016 * \mathrm{R}$} & $0.1852 * * *$ & $0.1488^{* * *}$ & $0.1621 * * *$ & $-0.2827 * * *$ & $-0.1748 *$ & $-0.1540 *$ \\
\hline & $(0.0397)$ & $(0.0384)$ & $(0.0381)$ & $(0.0954)$ & $(0.0936)$ & $(0.0971)$ \\
\hline \multirow[t]{2}{*}{ Observations } & 9,978 & 9,978 & 9,978 & 4,566 & 4,566 & 4,566 \\
\hline & \multicolumn{3}{|c|}{ Hourly salary } & \multicolumn{3}{|c|}{ Weekly hours worked } \\
\hline \multirow[t]{2}{*}{ D2016 } & $0.1306^{* * *}$ & $0.0702 * * *$ & $0.0849 * * *$ & -0.0011 & 0.0125 & 0.0139 \\
\hline & $(0.0180)$ & $(0.0201)$ & $(0.0195)$ & $(0.0012)$ & $(0.0143)$ & $(0.0152)$ \\
\hline \multirow[t]{2}{*}{$\mathrm{R}$} & $-0.2865 * * *$ & $-0.1830 * * *$ & $-0.2033^{* * *}$ & $-0.0920 * *$ & $-0.0821 *$ & $-0.0819 *$ \\
\hline & $(0.0570)$ & $(0.0624)$ & $(0.0603)$ & $(0.0439)$ & $(0.0456)$ & $(0.0473)$ \\
\hline \multirow[t]{2}{*}{$\mathrm{D} 2016 * \mathrm{R}$} & $-0.1632 * *$ & -0.1302 & -0.1204 & -0.0483 & -0.0100 & -0.0054 \\
\hline & $(0.0787)$ & $(0.0840)$ & $(0.0842)$ & $(0.0589)$ & $(0.0578)$ & $(0.0613)$ \\
\hline Observations & 4,751 & 4,751 & 4,751 & 6,465 & 6,465 & 6,465 \\
\hline Country of orig & & $\mathrm{X}$ & $\mathrm{X}$ & & $\mathrm{X}$ & $X$ \\
\hline Other controls & & $X$ & $X$ & & $\mathrm{X}$ & $X$ \\
\hline LA FE & & & $X$ & & & $X$ \\
\hline
\end{tabular}

Notes: Weekly earnings, hourly salary and weekly hours worked are included in logs in the estimation. Standard errors are included in parenthesis. Other controls include time in the UK dummies, gender, age (a quartic), marital status, education, religion, health status and UK nationality. The estimation only includes foreign-born individuals. ***indicates significant at $1 \%$ level, **indicates significant at $5 \%$ level, *indicates significant at $10 \%$ level. 
Table 12 - Health conditions limiting work

\begin{tabular}{|c|c|c|c|c|}
\hline \multirow[t]{2}{*}{ Health condition } & \multicolumn{3}{|c|}{ Mean values for dummy (yes $=1$ ) } & \multirow{2}{*}{$\begin{array}{c}\text { Regression results } \\
\text { Full sample } \\
\text { (4) }\end{array}$} \\
\hline & $\begin{array}{c}\text { Natives } \\
\text { (1) }\end{array}$ & $\begin{array}{l}\text { Asylum } \\
\text { (2) }\end{array}$ & $\begin{array}{l}\text { Other } \\
\text { migrants } \\
\text { (3) }\end{array}$ & \\
\hline Limits kind of work & 0.4949 & 0.6909 & 0.5157 & $\begin{array}{c}0.1395 * * * \\
(0.0181)\end{array}$ \\
\hline Limits amount of work & 0.4463 & 0.6815 & 0.4793 & $\begin{array}{c}0.1671 * * * \\
(0.0184)\end{array}$ \\
\hline Mental & 0.1822 & 0.1680 & 0.1278 & $\begin{array}{c}0.0284 * * \\
(0.0165)\end{array}$ \\
\hline Seeing, hearing, speak & 0.0231 & 0.0187 & 0.0204 & $\begin{array}{l}-0.0051 \\
(0.0046)\end{array}$ \\
\hline Extremities, back, neck & 0.1678 & 0.2049 & 0.1930 & $\begin{array}{l}0.0273 * \\
(0.0151)\end{array}$ \\
\hline Respiratory & 0.1103 & 0.0632 & 0.0839 & $\begin{array}{c}-0.0287 * * * \\
(0.0082)\end{array}$ \\
\hline Hearth & 0.1212 & 0.1300 & 0.1458 & $\begin{array}{c}0.0067 \\
(0.0144)\end{array}$ \\
\hline Stomach & 0.0678 & 0.0785 & 0.0656 & $\begin{array}{c}0.0067 \\
(0.0100)\end{array}$ \\
\hline Diabetes & 0.0618 & 0.1136 & 0.1297 & $\begin{array}{l}-0.0123 \\
(0.0127)\end{array}$ \\
\hline Others & 0.2657 & 0.2237 & 0.2337 & $\begin{array}{l}-0.0229 \\
(0.0152)\end{array}$ \\
\hline Observations & 92,386 & 854 & 9,709 & 102,949 \\
\hline $\begin{array}{l}\text { Other controls } \\
\text { LA FE }\end{array}$ & & & & $\begin{array}{l}X \\
X\end{array}$ \\
\hline
\end{tabular}

Notes: Mental includes phobias, panics, depression or other nervous disorders. Extremities include arthritis, rheumatism or other problems related to arms, hands, legs or feet. Column 4 reports the coefficients of the dummy variable indicating that the person migrated to claim asylum in a regression with the health condition as dependant variable. Standard errors are included in parenthesis. Other controls include gender, age (a quartic), marital status, education, religion and UK nationality. Standard errors are included in parenthesis. ***indicates significant at $1 \%$ level, **indicates significant at 5\% level, *indicates significant at $10 \%$ level. 
Table 13 - Labour market outcomes: UK-born versus foreign-born from English speaking countries

\begin{tabular}{lcccc}
\hline Reason for migration & & \multicolumn{2}{c}{ Dependent variable } \\
(reference is UK-born) & In employment & Weekly earnings & Hourly salary & Hours worked \\
\hline \multirow{2}{*}{ Work } & -0.0090 & $-0.0546^{* *}$ & $-0.1122^{* * *}$ & $0.0492^{* * *}$ \\
& $(0.0077)$ & $(0.0228)$ & $(0.0191)$ & $(0.0107)$ \\
Study & $-0.0404 * * *$ & $-0.1970 * * *$ & $-0.2063 * * *$ & 0.0008 \\
& $(0.0096)$ & $(0.0274)$ & $(0.0234)$ & $(0.0128)$ \\
Family & $-0.1334 * * *$ & $-0.3798^{* * *}$ & $-0.3357 * * *$ & $-0.0649 * * *$ \\
& $(0.0097)$ & $(0.0257)$ & $(0.0199)$ & $(0.0134)$ \\
Asylum & $-0.1261 * * *$ & $-0.4768^{* * *}$ & $-0.4532 * * *$ & -0.0407 \\
& $(0.0209)$ & $(0.0477)$ & $(0.0431)$ & $(0.0268)$ \\
Other & $-0.0877 * * *$ & $-0.3342^{* * *}$ & $-0.3157 * * *$ & $-0.0314 * *$ \\
Observations & $(0.0106)$ & $(0.0299)$ & $(0.0236)$ & $(0.0160)$ \\
& 297,302 & 160,307 & 159,098 & 203,385 \\
Controls & & & & \\
LA FE & $\mathrm{X}$ & $\mathrm{X}$ & $\mathrm{X}$ & $\mathrm{X}$ \\
\hline
\end{tabular}

Notes: Weekly earnings, hourly salary and hours worked are included in logs in the estimation. English speaking countries are defined as those in which English is used as a language of instruction in higher education. Controls include gender, age (a quartic), marital status, education, religion, health status and UK nationality. Standard errors are included in parenthesis. $* * *$ indicates significant at $1 \%$ level, **indicates significant at $5 \%$ level. 